Supplementary information

\title{
Enhanced Ion Sieving of Graphene Oxide Membranes via Surface Amine Functionalization
}

Yijun Qian ${ }^{1}$, Jing Shang ${ }^{2}$, Dan Liu ${ }^{1, *}$, Guoliang Yang, Xungai Wang ${ }^{1}$, Cheng Chen $^{3}$, Liangzhi Kou ${ }^{2, *}$, Weiwei Lei ${ }^{1, *}$

1. Deakin University, Institute for Frontier Materials, Waurn Ponds Campus, Locked Bag 20000, Geelong, Victoria 3220, Australia

2. School of Mechanical Medical \& Process Engineering, Queensland University of Technology, Brisbane, Queensland, 4000, Australia

3. School of Resources and Environment, Anhui Agricultural University, Hefei, 230036, China

*Corresponding Authors E-mails: dan.liu@deakin.edu.au, liangzhi.kou@qut.edu.au,

weiwei.lei@deakin.edu.au 
1. Photography of PECVD.

Error! Bookmark not defined.

2. Characterizations of FGOMs and GOMs (AFM, SEM, FTIR, XPS, Contact angle, XRD, Zeta potential and Raman). Error! Bookmark not defined.

3. Photography of H-Cell. Error! Bookmark not defined.

4. The relationship between individual ionic permeation rate and effective nanochannel height of GOM and FGOMs. Error! Bookmark not defined.

5. The relationship between permeation rate and the cation-to-anion valence ratio $\left(Z^{+} / Z^{-}\right)$. Error! Bookmark not defined.

6. Mono-/di-valent cationic ion selectivity of GOM and FGOMs in binary ion permeation tests. Error! Bookmark not defined.

7. Temperature dependence of the $\mathrm{Na}^{+}$permeation rate passing through the GOM and FGOM30. Error! Bookmark not defined.

8. The relationship between divalent ion permeance and content of amine groups in FGOMs. Error! Bookmark not defined.

9. Effects of nitrogen configuration of FGOMs on cationic ion permeation behaviour through FGOMs. Error! Bookmark not defined.

10. DFT stimulation of binding energies of $\mathrm{Na}^{+}$and $\mathrm{Mg}^{2+}$ with polarized nitrogen atoms in graphene nanohsheet. Error! Bookmark not defined.

11. Effect of $\mathrm{Na}^{+}$concentration on $\mathrm{Na}^{+}$permeation behaviour through FGOM-30. Error! Bookmark not defined.

12. Effect of $\mathrm{Na}^{+}$permeation behaviour through FGOM-30 with different thickness. Error! Bookmark not defined.

13. Water permeance and $\mathrm{NaCl}$ rejection of GOM and FGOMs using osmosis-driven pressure. Error! Bookmark not defined.

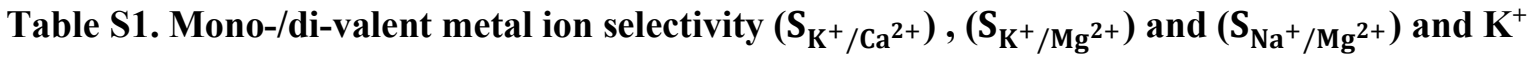
permeance $\left(\mathrm{K}_{\mathrm{K}^{+}}\right)$achieved by various types of artificial channels and 2D nanomaterial membranes with different thickness measured under different feed electrolyte solution concentrations $\left(\mathbf{C}_{\text {feed }}\right)$............................................................................... Error! Bookmark not defined

Table S2. Comparison of the 2D nanomaterial membranes for water/salt separation in a diffusion cell, where water/salt selectivity represents $\left(J_{\mathrm{w}} / J_{\mathrm{s}}\right)$ and osmotic pressure is calculated by van't Hoff equation $\left(* \Delta \pi_{\text {theo }}\right)$ Error! Bookmark not defined.

Table S3. Comparison of the desalination performance of various lamellar membranes. .... Error! Bookmark not defined.

Reference Error! Bookmark not defined. 


\section{Photography of PECVD.}
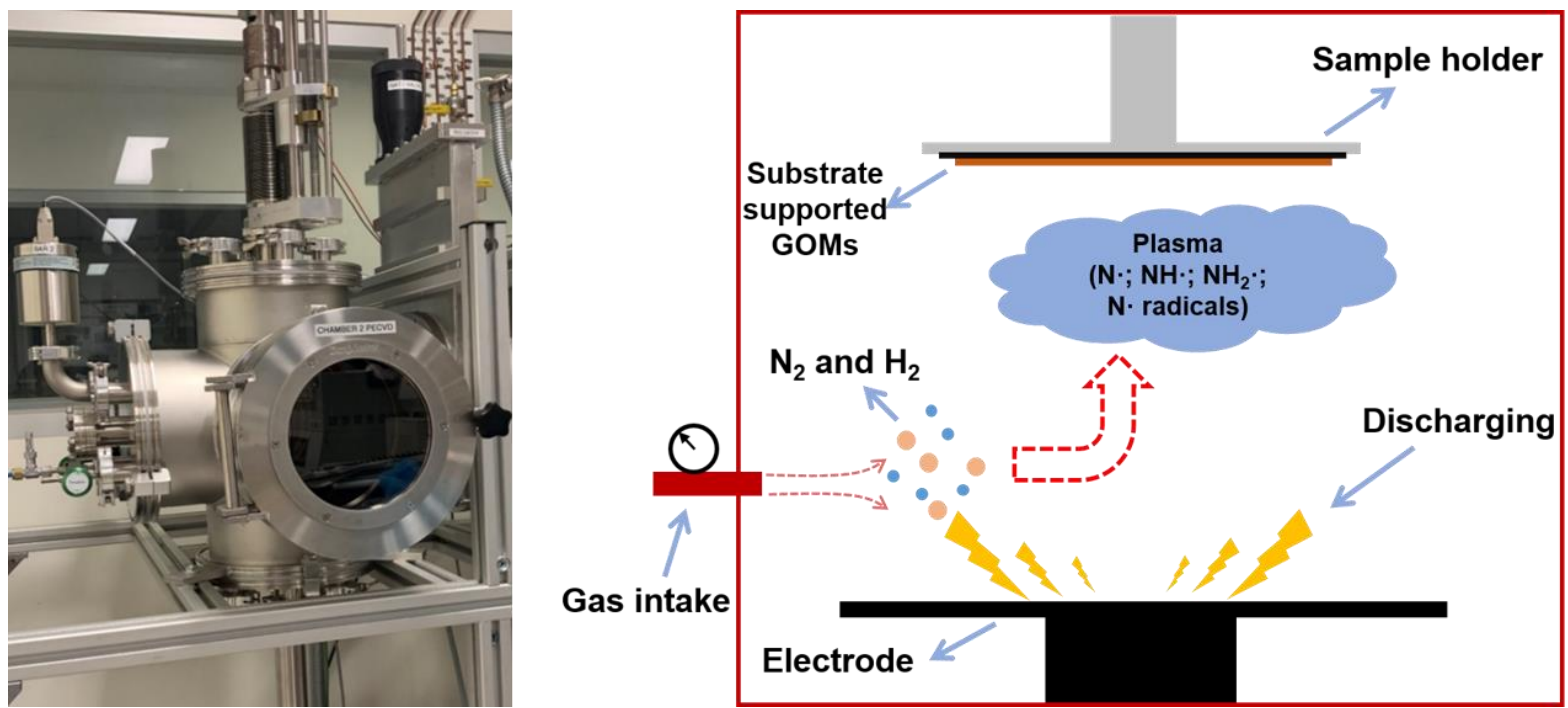

Figure S1. Photography of the home-made PECVD system and schematic of its inner chamber during plasma functionalisation.

The mixed $\mathrm{N}_{2} / \mathrm{H}_{2}$ gas carrier can be ionized into different types of radicals, electrons and photons, and the active radicals can react with oxygen functionalities, defects and carbon atom in GO nanosheets ${ }^{1}$.

$$
\mathrm{N}_{2}+\mathrm{H}_{2} \rightarrow \mathrm{N} \cdot+\mathrm{NH} \cdot+\mathrm{NH}_{2} \cdot+\mathrm{H} \cdot+\text { electrons }+ \text { photons }
$$




\section{Characterizations of FGOMs and GOMs (AFM, SEM, FTIR, Contact angle, XRD, Zeta potential and Raman).}
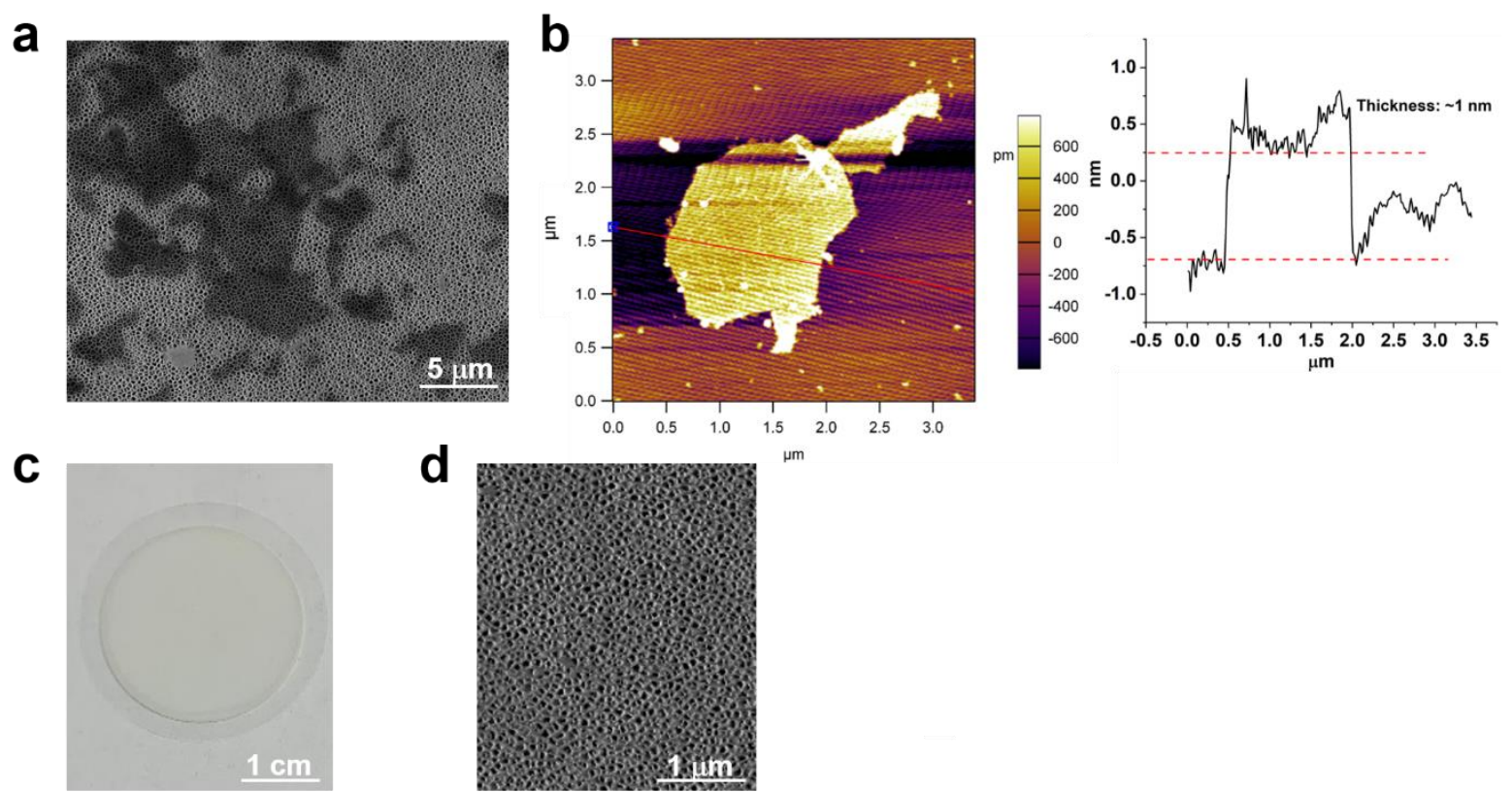

Figure S2. (a) SEM image of the GO nanosheets deposited on the anodic aluminium oxide (AAO) substrate. (b) AFM image of GO nanosheets. The thickness of GO nanosheets is around $1 \mathrm{~nm}$, which indicates the mono-/bilayer of the GO nanosheets. (c and d) Photo of bare AAO substrate and the corresponding surface morphology (SEM) of AAO supporter. 

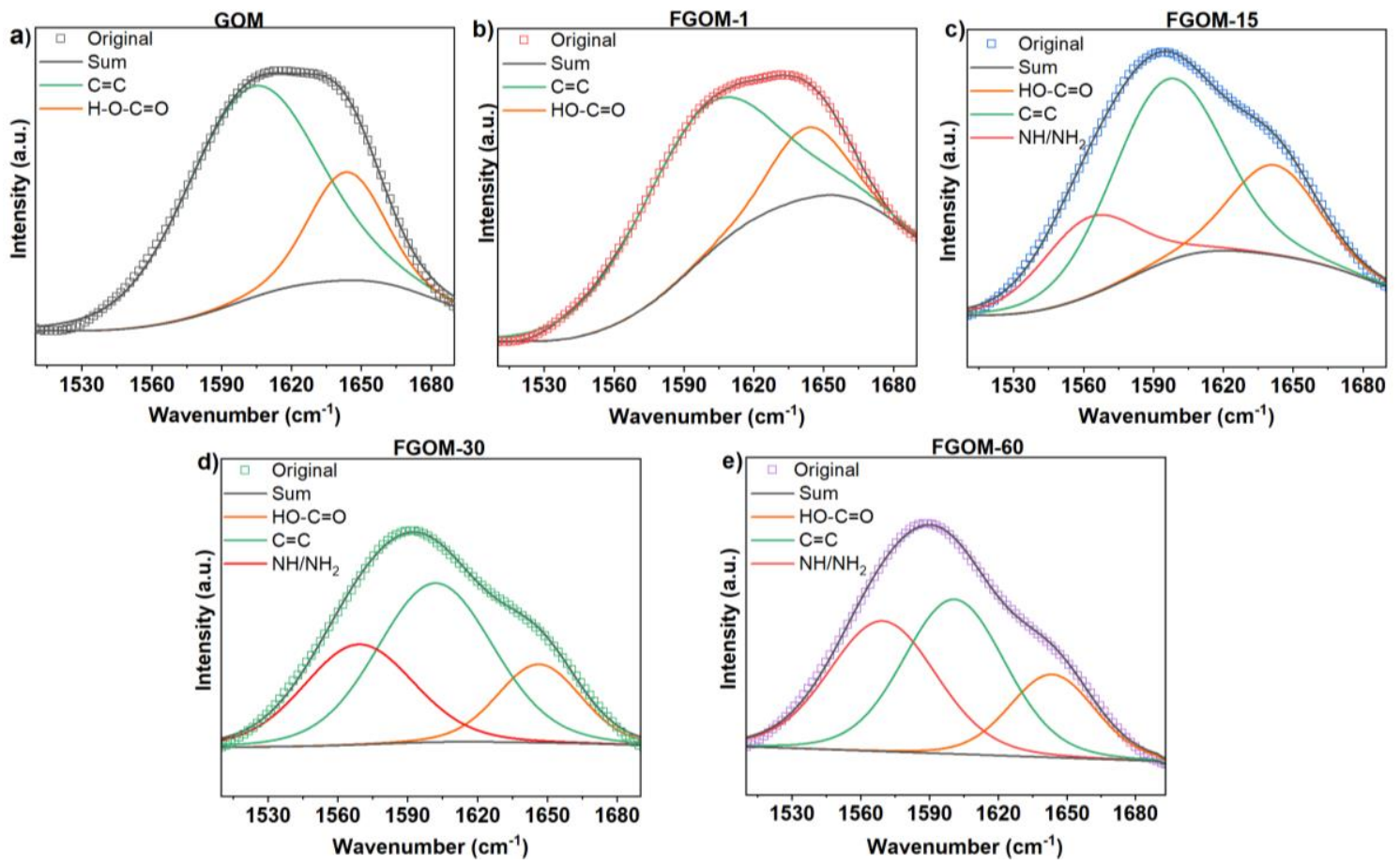

Figure S3. (a-e) The FTIR spectra of GOM and FGOMs with wavenumber from 1500 to $1700 \mathrm{~cm}^{-1}$ and their corresponding deconvolution spectra. 
a
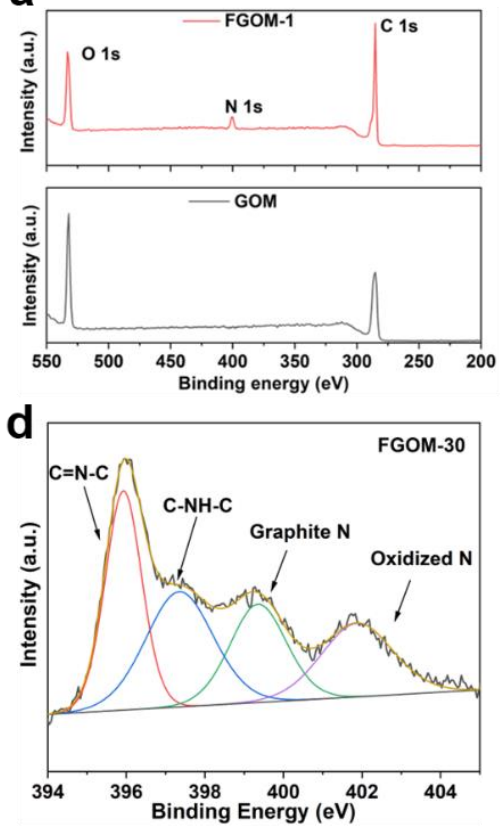

b

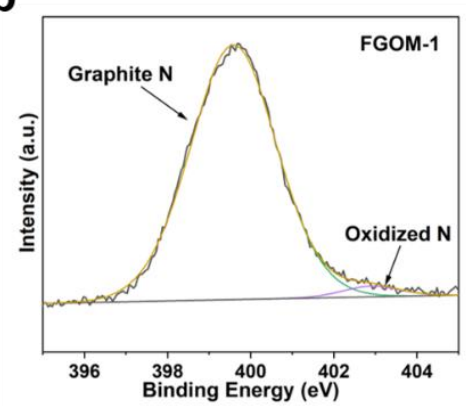

e

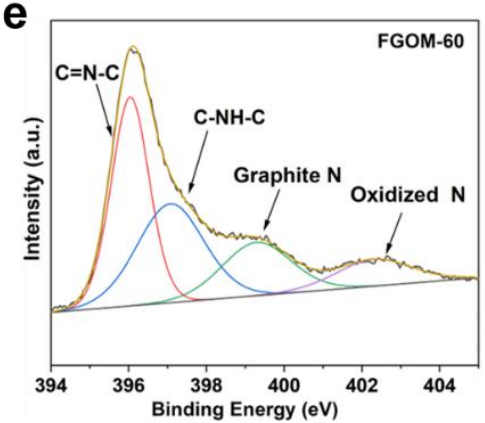

C

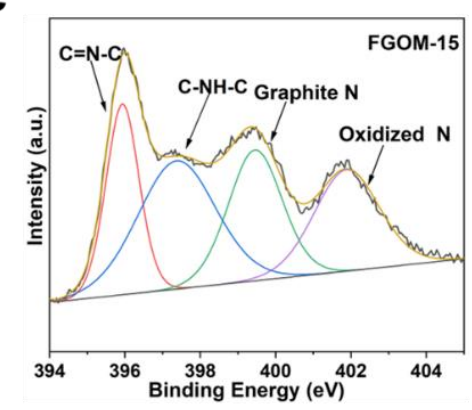

f

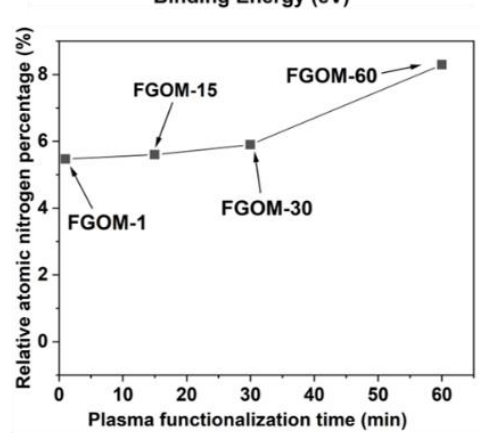

Figure S4. (a) XPS survey of GOM and FGOM-1(as representative). (b-e) High-resolution N1s spectra of FGOMs. (f) Relatives atomic nitrogen percentage of FGOMs after plasma processing. The elemental nitrogen appeared in FGOM-1, indicating the successful plasma functionalisation of FGOMs after a short-time plasma processing treatment. 


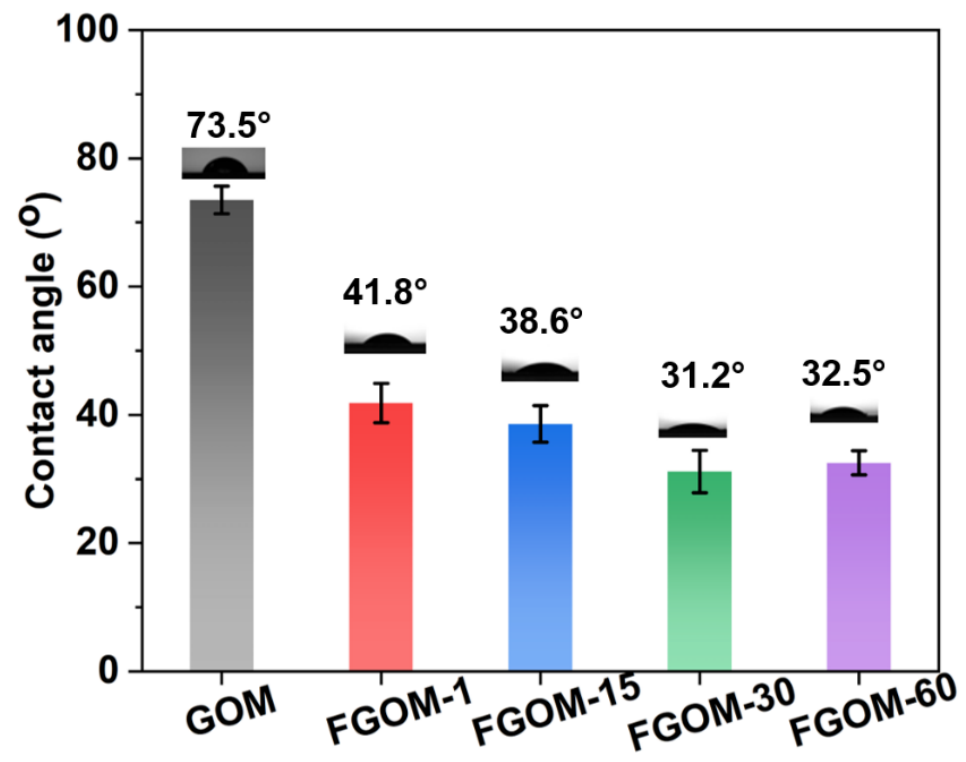

Figure S5. The water contact angles of GOMs and FGOMs. The hydrophilicity of GOM was improved after plasma functionalisation, which can be attributed to the appearance of the amine functionality. 


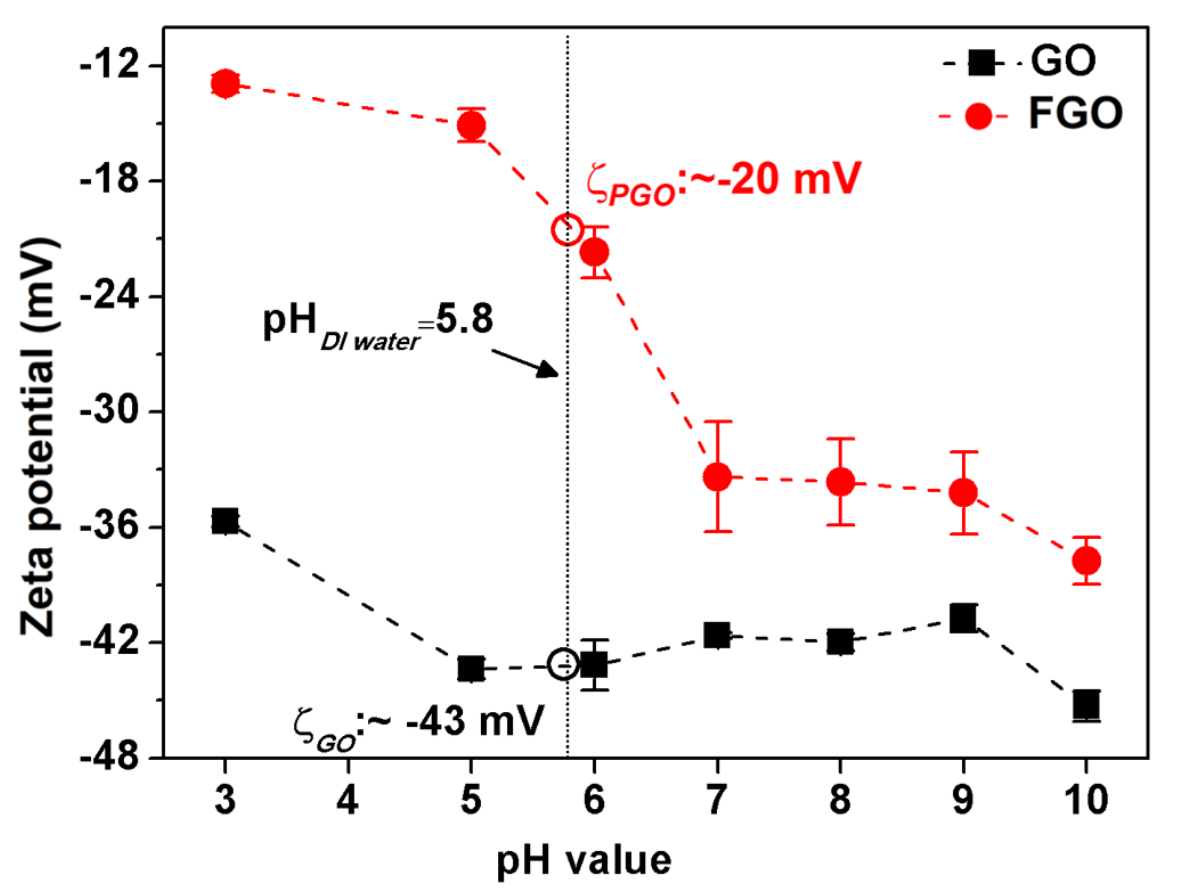

Figure S6. Zeta potentials of FGO and GO aqueous dispersions. Note: the GO and PGO dispersions were prepared via redispersing GOM and FGOM-30 in water. The corresponding concentration of GOM and PGO dispersion is $1 \mathrm{mg} / \mathrm{mL}$. The zeta potentials of $\mathrm{GO}$ and $\mathrm{FGO}$ were tested in water at different $\mathrm{pH}$ values to analyse the surface charge in an aqueous solution. GO dispersion exhibited highly negative potential value between $-45.0 \mathrm{mV}$ and $-36.0 \mathrm{mV}$ both in base and acid aqueous environments, consistent with the reported value of GO materials due to plenty of oxygen functionalities ${ }^{2}$. In contrast, a lower negative potential value ranging from $-37.0 \mathrm{mV}$ and $-13.0 \mathrm{mV}$ was observed for FGO after plasma functionalisation. In particular, a sharp decrease of zeta potential value from $-33 \mathrm{mV}$ to $-21 \mathrm{mV}$ occurred when the dispersion was turned into weak acid. Due to utilization of neutral salts in this study, the corresponding $\mathrm{pH}$ value of each salt solution is equal to that of DI water, revealing weakly acidic at around $\mathrm{pH}=5.8$. Therefore, the zeta potential values of $\mathrm{GO}$ and $\mathrm{FGO}$ at around $\mathrm{pH}=5.8 \mathrm{enable}$ to reflect the corresponding realistic surface charge information in this study. Apparently, FGO displayed a more positive potential value of around $-21 \mathrm{mV}$ than that of $\mathrm{GO}(-43 \mathrm{mV})$, revealing a decreased absolute value of $22 \mathrm{mV}$ after plasma functionalisation. The reduced negative zeta potential value after plasma processing can be attributed to two factors. Firstly, the incorporated amine groups experience protonation process in weak acid and then neutralize the instinct negatively charged oxygen functional groups from GO on the contact with water, showing a slight decrease in zeta potential value. Similar observation has been reported by previous studies ${ }^{3}$. Secondly, plasma functionalisation is the surface-oriented modification technology and cannot change or deteriorate the GOM inner structure. Thus, the redispersed FGO with plenty of unfunctionalized GO in aqueous solution enables to block or neutralize the positively charged FGO, consequently causing a somewhat negatively charged potential of FGO dispersion. 


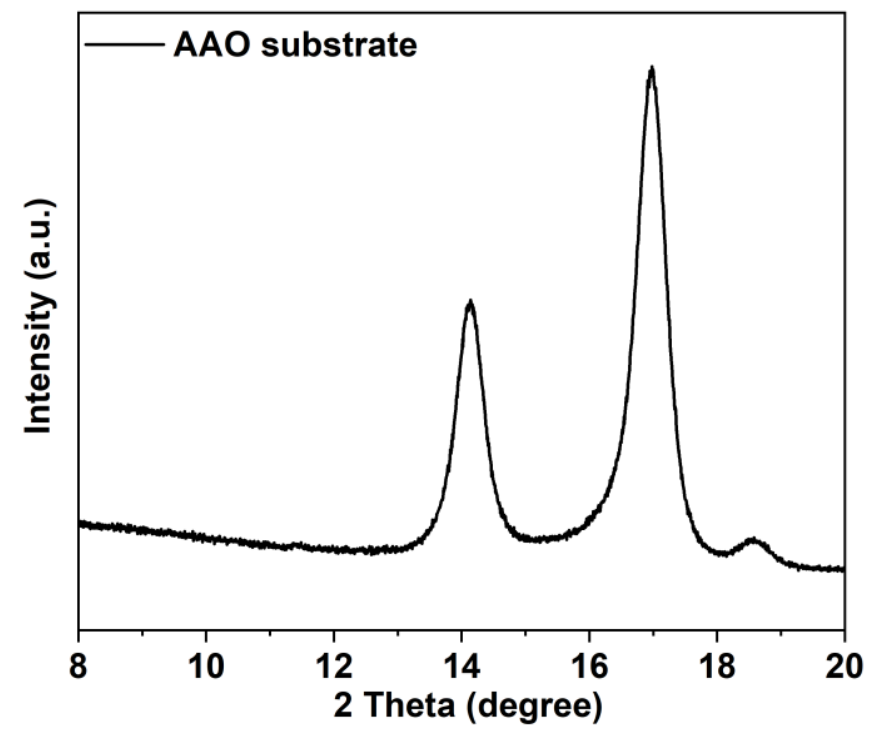

Figure S7. (a) XRD pattern of AAO bare substrate. 

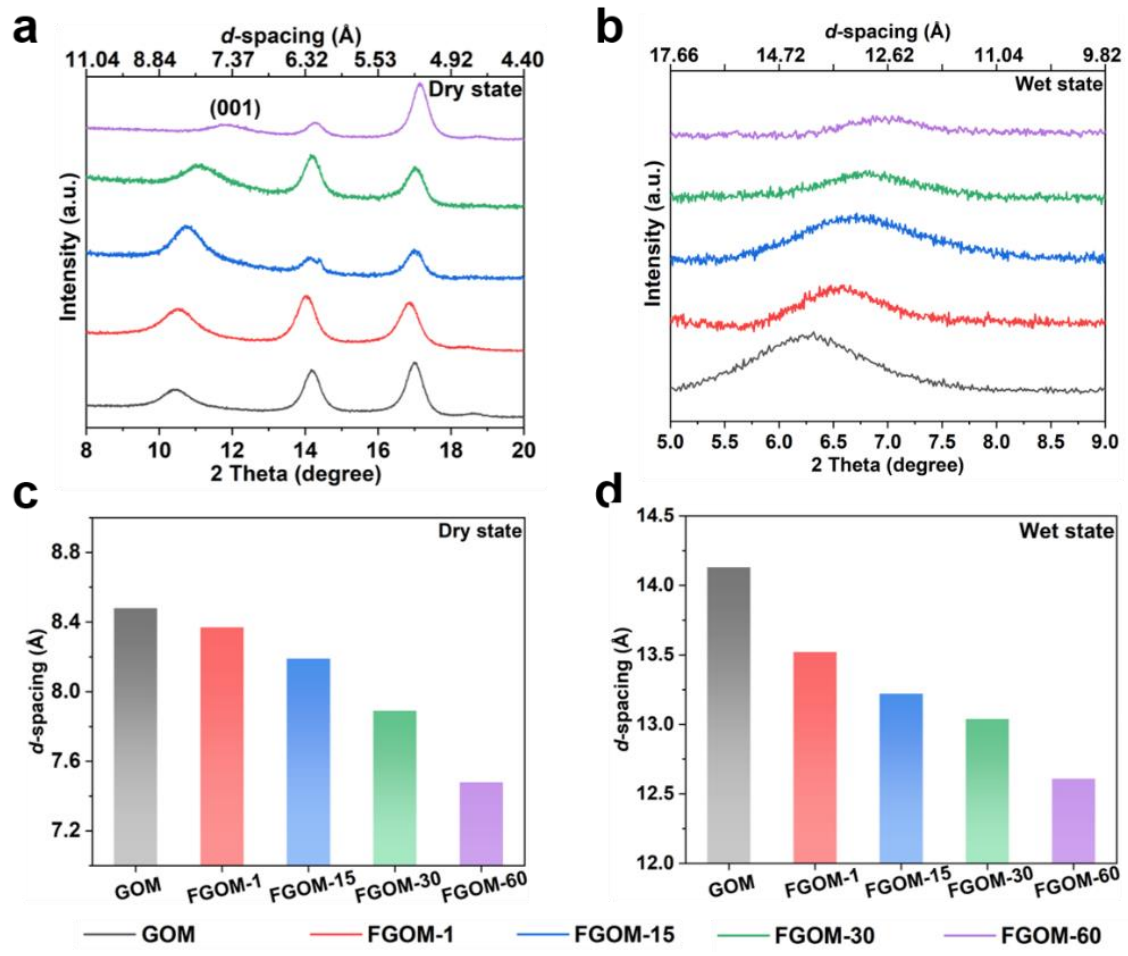

Figure S8. (a and b) XRD patterns of GOM and FGOMs in the dry state and wet state and (c and d) their corresponding $d$ spacings calculated by (001) peak. 


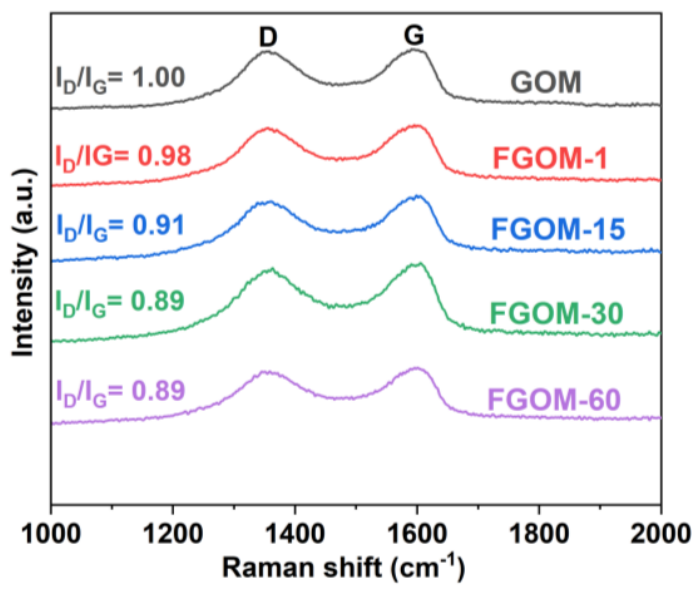

Figure S9. Raman spectra of GOM and FGOMs.

Table 1. Comparison of $\mathrm{ID}_{\mathrm{D}} / \mathrm{IG}_{\mathrm{G}}, \mathrm{LD}_{\mathrm{D}}$ and $n_{D}$ for GOMs and FGOMs analysed by Raman spectra.

\begin{tabular}{cccc}
\hline Membranes & $\mathbf{I}_{\mathbf{D}} / \mathbf{I}_{\mathbf{G}}$ & $\mathbf{L}_{\boldsymbol{D}}(\mathbf{n m})$ & $\boldsymbol{n}_{\boldsymbol{D}}\left(\mathbf{c m}^{-\mathbf{2}}\right)$ \\
\hline GOM & 1.00 & 11.21 & $7.60 \times 10^{-3}$ \\
\hline FGOM-1 & 0.98 & 11.32 & $7.80 \times 10^{-3}$ \\
\hline FGOM-15 & 0.91 & 11.75 & $7.24 \times 10^{-3}$ \\
\hline FGOM-30 & 0.89 & 11.88 & $7.09 \times 10^{-3}$ \\
\hline FGOM-60 & 0.89 & 11.88 & $7.09 \times 10^{-3}$ \\
\hline
\end{tabular}

Note: the excitation laser wavelength in this study is $514 \mathrm{~nm}$.

The intensity ratio of $\mathrm{I}_{\mathrm{D}} / \mathrm{I}_{\mathrm{G}}$ is slightly decreased from 1.00 of pristine GOM to 0.89 of FGOM- 60 . The Raman analysis is based on the model that a defect on the graphene surface causes a circular structural disorder area (region $\mathrm{S}$ ), which is surrounded by a so-called activated region (region A). The area without any structural disorder areas contributes to the G band, whilst the distance between the neighbouring disorder areas leads to the D band. D band can be weakly affected by the structural disorder region S due to the breakdown of the lattice structure. Besides, the defects brought by physical method (e.g. low fluence induced ion beam and plasma irradiation) mostly contribute to long distance between the neighbouring defect, and the mean distance between defect $\left(\mathrm{L}_{\mathrm{D}}\right)$ is usually many times of the size of defect. Based on the previous results reported by Cancado et al. ${ }^{4}$, for low-defect density regime $\left(\mathrm{L}_{\mathrm{D}} \geq 10 \mathrm{~nm}\right)$ with the radius difference between region $\mathrm{A}$ and region $\mathrm{S}$ (i.e. $\mathrm{r}_{\mathrm{A}}$ rs) of 1-2 nm, LD could be described as:

$$
\mathrm{L}_{D}(n m)=\sqrt{(1.8 \pm 0.5) \times 10^{-9} \lambda_{L}^{4}\left(\frac{I_{D}}{I_{G}}\right)^{-1}}
$$

where $\lambda_{L}(\mathrm{~nm})$ is the excitation laser wavelength.

The defect density $\mathrm{n}_{D}$ can be expressed as:

$$
n_{D}\left(c m^{-2}\right)=\frac{1}{L_{D}^{2}}
$$

Although the defect density mentioned here is the density of structural defects in the GO layers, which cannot be used to describe the corresponding point defects on the GO surface. However, the value of defect densities created by the plasma processing in this study (Table 1.) is similar to the previous results reported by Cancado et al, which indicates that nanometre scale point defects around 1-2 nm were generated by the plasma radiation (e.g. substitutional atoms) ${ }^{4}$. Therefore, the point defects in FGOMs do not exert a strong influence on $\mathrm{I}_{\mathrm{D}} / \mathrm{I}_{\mathrm{G}}$. Further analysis on $\mathrm{G}$ band from Raman spectra can provide more information on point defects created by plasma processing, however, different from pure graphene, the charged impurities, strain and intercalants in FGOMs are influential to the G peak, which make it difficult to analyse. 


\section{Photography of H-Cell.}

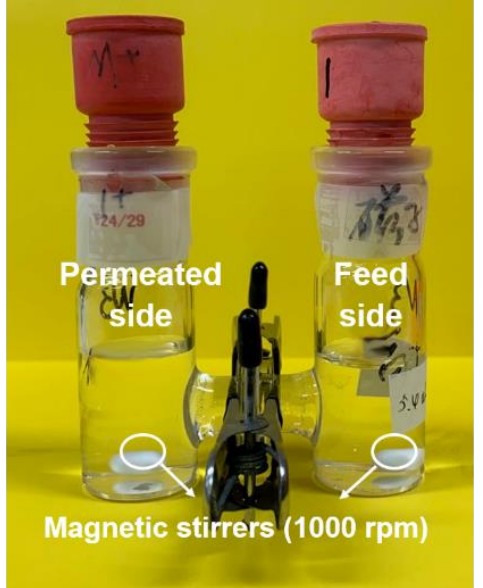

Figure S10. The home-made H-cell for ion permeation tests.
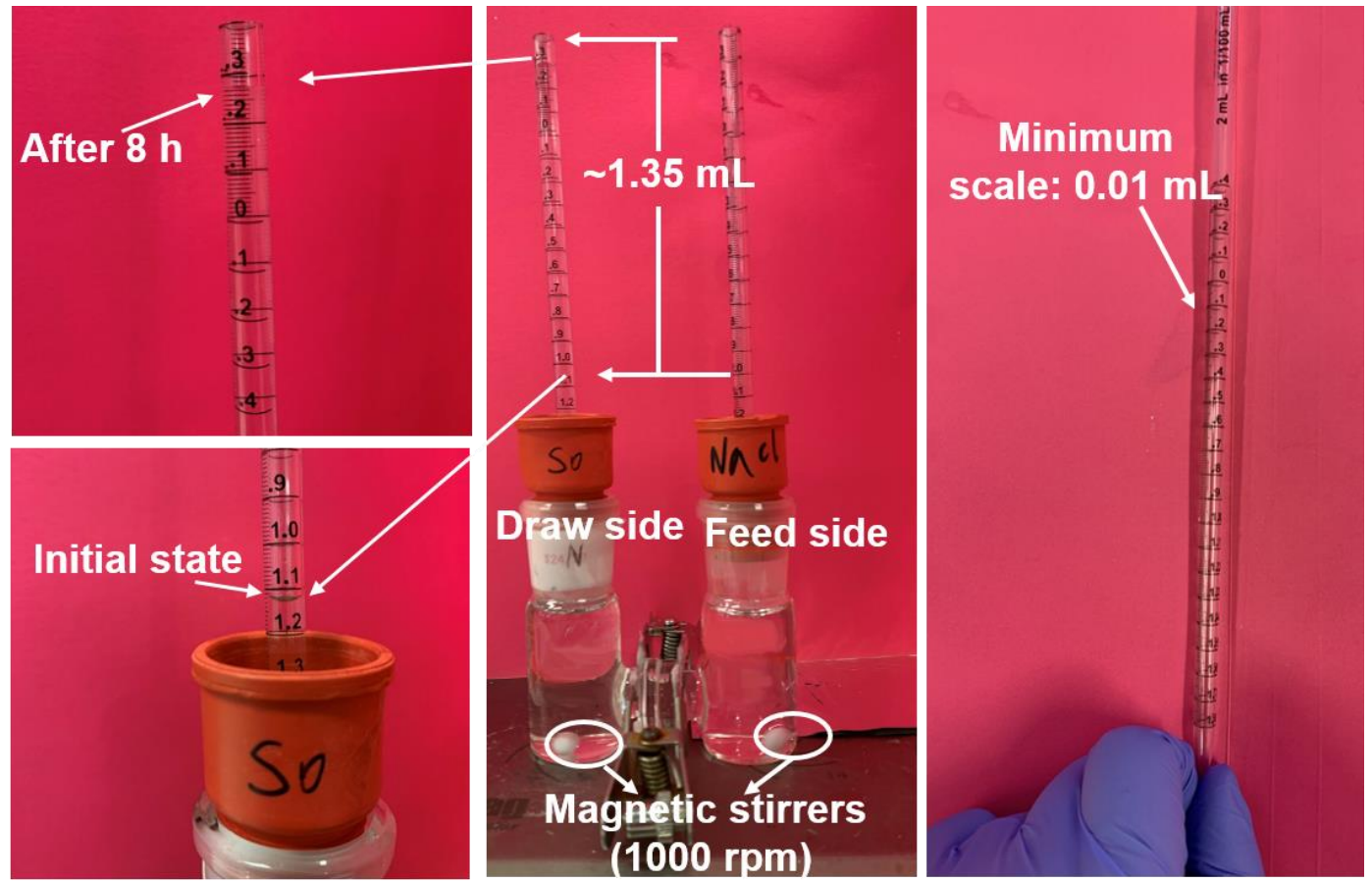

Figure S11. The home-made H-cell for forward osmosis tests. The increased volume of $\sim 1.35 \mathrm{~mL}$ was observed in the draw side after $8 \mathrm{~h}$. Note: the minimum scale of the tube is $0.01 \mathrm{~mL}$ and the inner diameter of the tube is around $5 \mathrm{~mm}$, which can inhibit the evaporation of water during forward osmosis test at the room temperature. 
4. The relationship between individual ionic permeation rate and effective nanochannel heights of GOM and FGOMs.

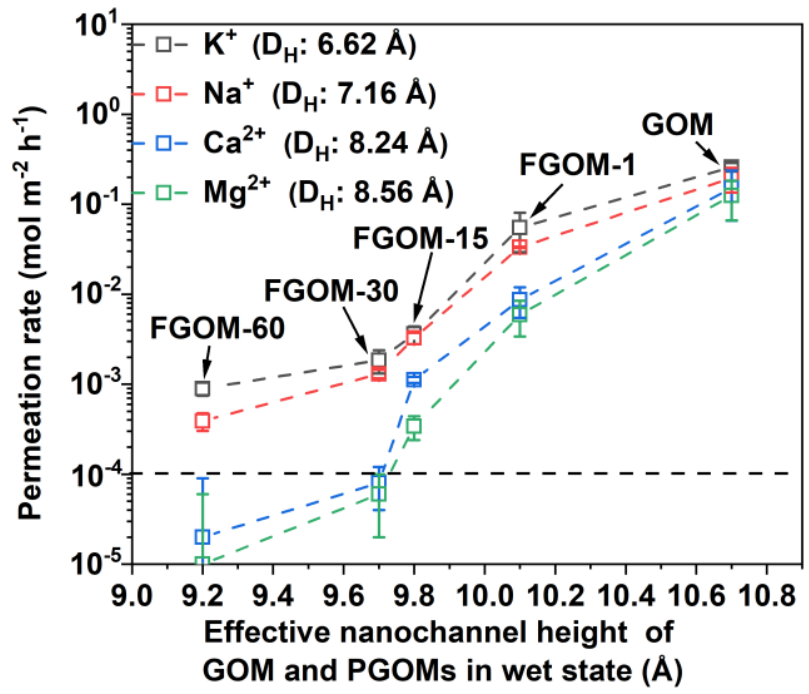

Figure S12. The permeation rates of each ions depend linearly on the effective nanochannel heights of GOM and FGOMs in wet state. The Y-error bars indicate the standard deviation. (Effective nanochannel height $=d$-spacing in the wet sate $-3.4 \AA$ (a monolayer of graphene nanosheets). 
5. The relationship between permeation rate and the cation-to-anion valence ratio $\left(Z^{+} / Z^{-}\right)$.

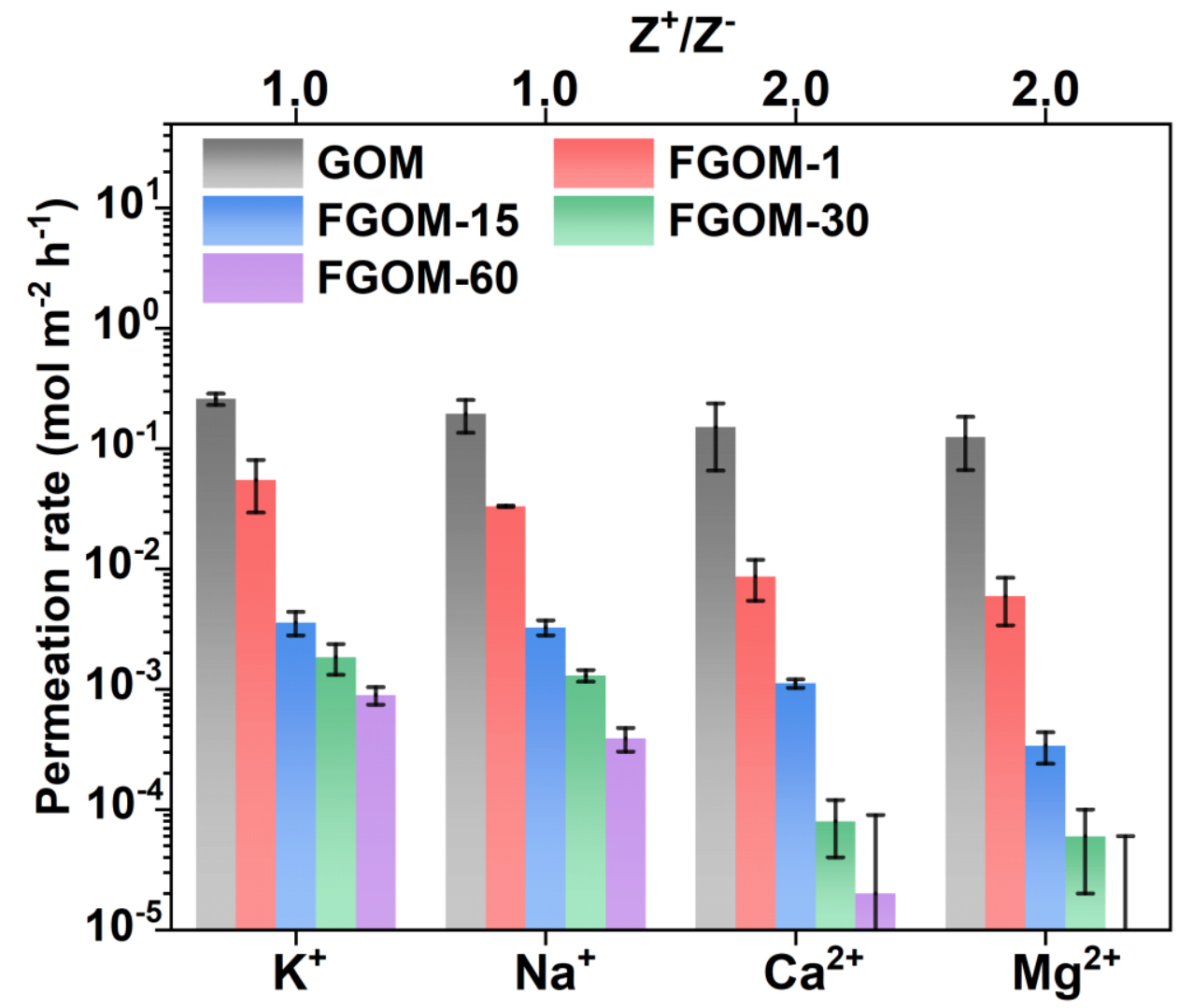

Figure S13. The relationship between permeation rate and the cation-to-anion valence ratio $\left(\mathrm{Z}^{+} / \mathrm{Z}^{-}\right)$. Feed solutions of $0.1 \mathrm{M}$ $\mathrm{KCl}, \mathrm{NaCl}, \mathrm{CaCl}_{2}$ and $\mathrm{MgCl}_{2}$ were selected, and DI water filled the permeated side. 
6. Mono-/di-valent cationic ion selectivity of GOM and FGOMs in binary ion permeation tests.

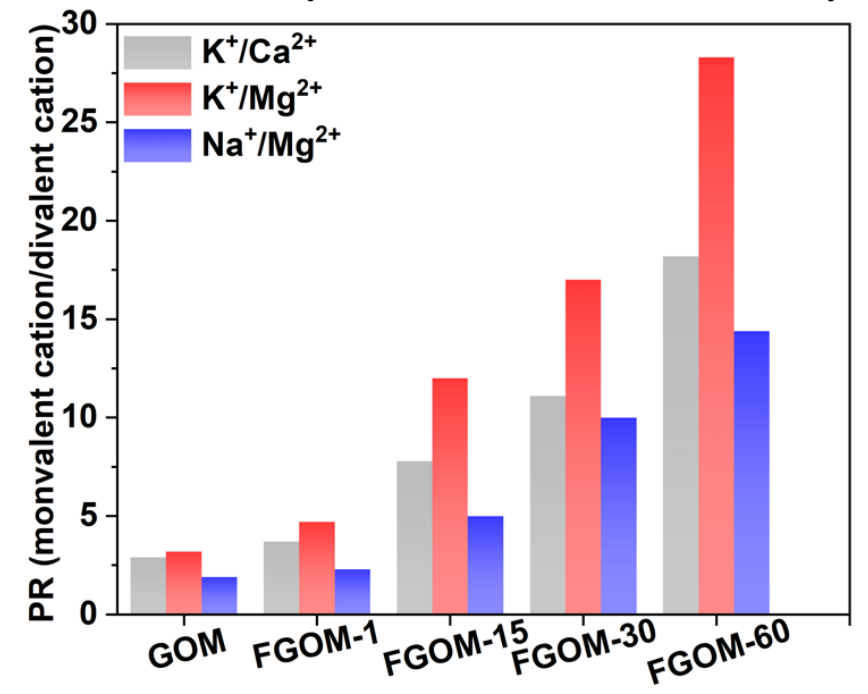

Figure S14. Separation factor of monovalent cationic/divalent cations in mixed solution. In this experiment, feed side was filled with $20 \mathrm{~mL}$ mixed solution ( $0.1 \mathrm{M}$ monovalent salt and $0.1 \mathrm{M}$ divalent salt), while the other side was filled with $20 \mathrm{~mL}$ DI water. The magnetic stirring was set up at $1000 \mathrm{rpm}$ to avoid the possible concentration polarization. The corresponding concentration of mono-/divalent cations in permeated side was detected by AAS. Therefore, the separation factor of mono-/divalent cation was calculated through the equation:

$$
\text { Separation factor of } \mathrm{A}^{+} / \mathrm{A}^{2+}=\frac{C_{m o n o}}{C_{d i}}
$$

Where $\mathrm{A}^{+}$and $\mathrm{A}^{2+}$ refer to monovalent cation and divalent cation respectively. $\mathrm{C}_{\mathrm{mono}}$ and $\mathrm{C}_{\mathrm{di}}$ is the concentration of monovalent cation and divalent cation in permeated side. 
7. Temperature dependence of the $\mathrm{Na}^{+}$permeation rate passing through the GOM and FGOM30.

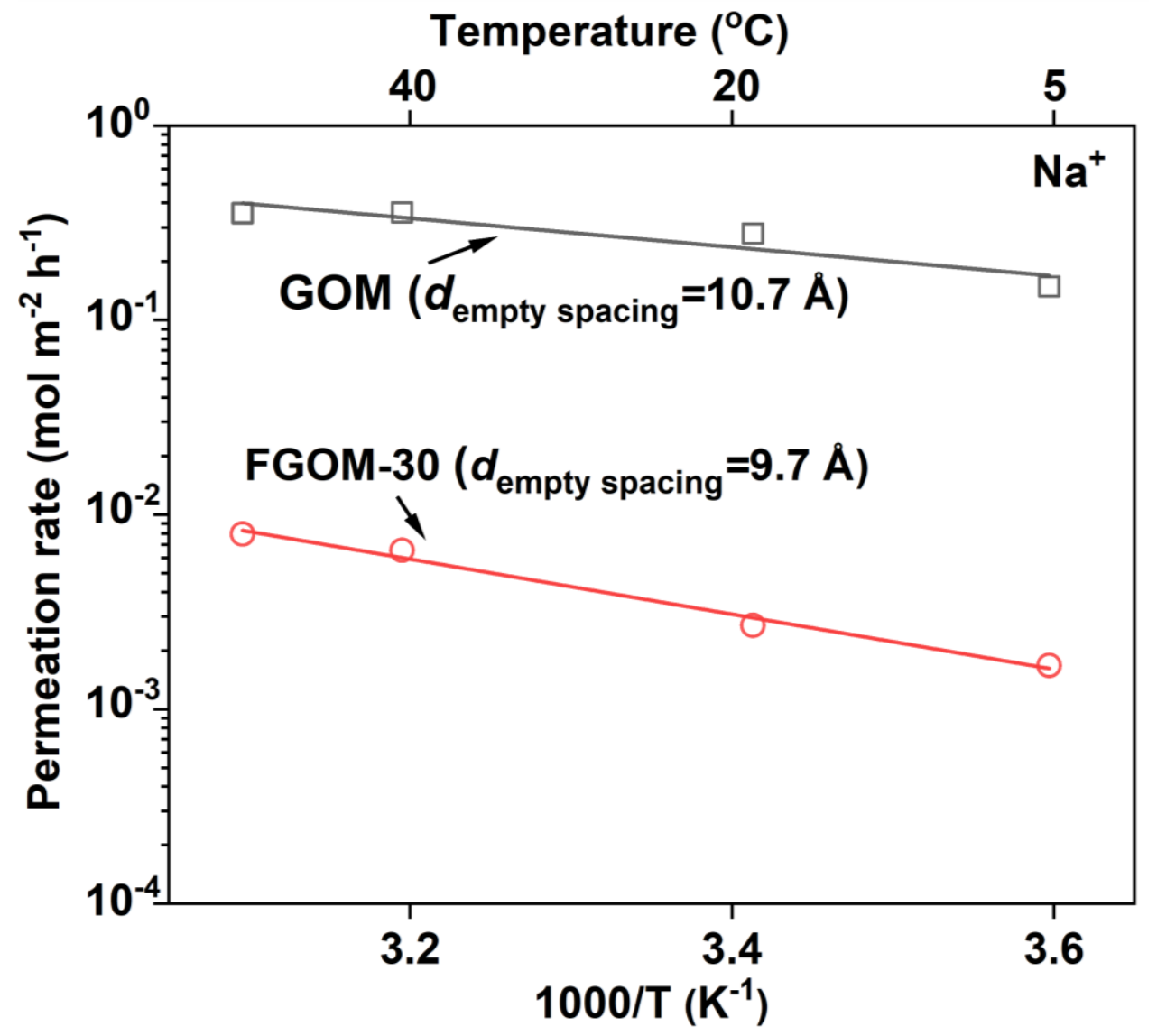

Figure S15. Temperature dependence of the $\mathrm{Na}^{+}$permeation rate passing through the GOM and FGOM-30. Dotted lines are best fitted to the Arrhenius behaviour. Note: $d_{\text {empty spacing }}=d$-spacing in the wet sate $-3.4 \AA$ (a monolayer of graphene nanosheets) 
8. The relationship between divalent ion permeance and content of amine groups in FGOMs.

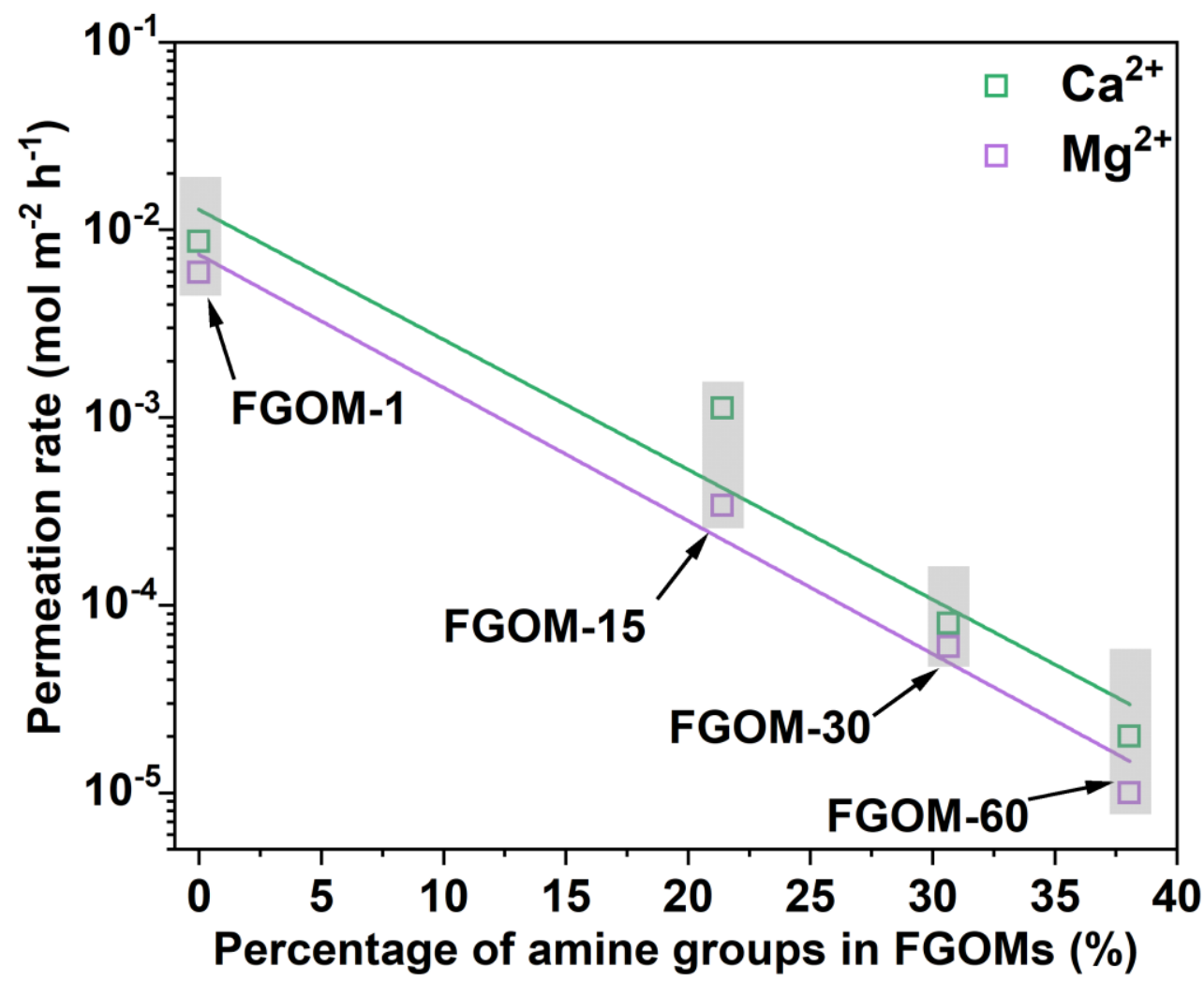

Figure S16. The permeation rates of cationic ions depend linearly on content of amine groups in FGOMs. 


\section{Effects of nitrogen configuration of FGOMs on cationic ion permeation behavior through}

FGOMs.

a

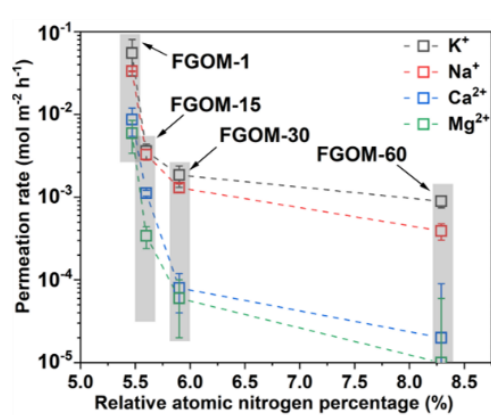

$\mathbf{b}_{1}$

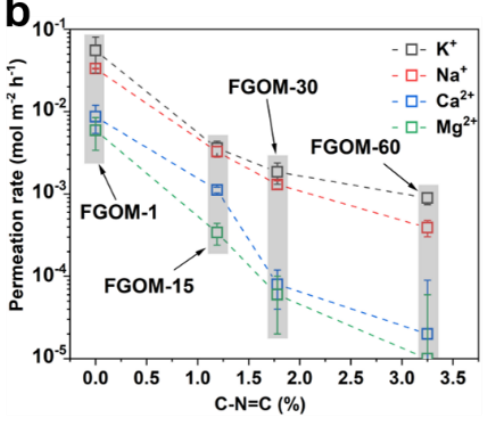

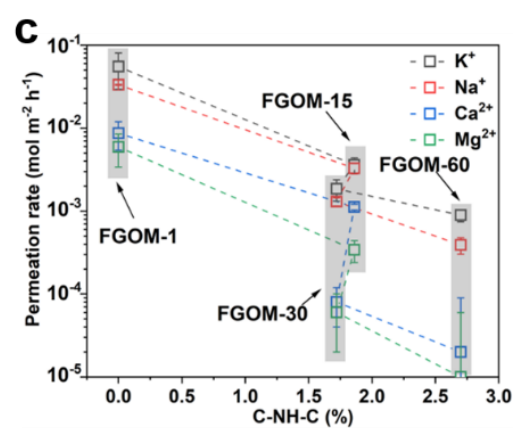

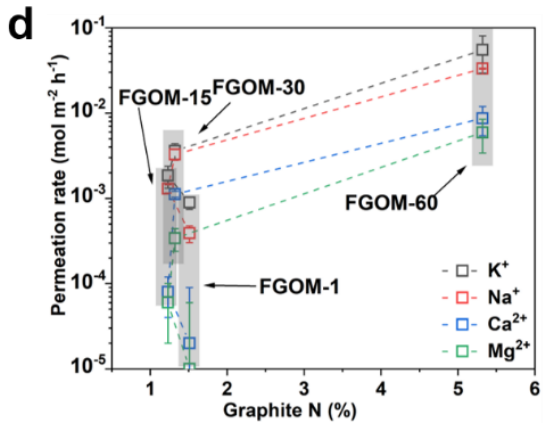

e

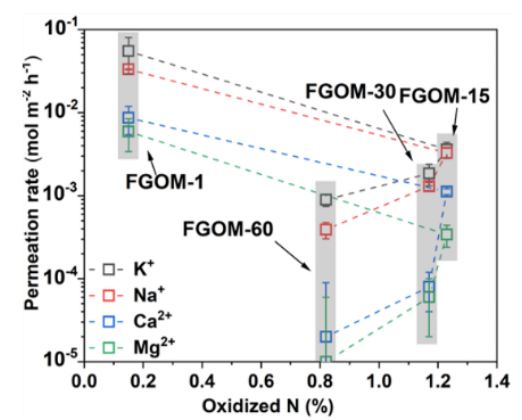

Figure S17. Effects of nitrogen configuration of FGOMs on cationic ion permeation behavior through FGOMs. We carried out the correlation analysis between ionic permeance $\left(\mathrm{K}^{+}, \mathrm{Na}^{+}, \mathrm{Ca}^{2+}\right.$ and $\left.\mathrm{Mg}^{2+}\right)$ and (a) atomic percent of nitrogen and (b-e) different nitrogen configuration. As shown in Figure S17a, the cationic permeance of all ions decreased with an increase in relative atomic nitrogen percentage, demonstrating an exponential decay function. Then, we found that apart from a linear relationship between ionic permeance and $\mathrm{C}-\mathrm{N}=\mathrm{C}(\%)$, irregular relationship was found between other nitrogen configurations (\%) and corresponding ionic permeance. This result can be attributed to the existence of polarized nitrogen atoms mainly in $\mathrm{C}-\mathrm{N}=\mathrm{C}$, where negatively charged atomic nitrogen enables to occur strong electrostatic attraction with cationic ions. 
10. DFT stimulation of binding energies of $\mathrm{Na}^{+}$and $\mathrm{Mg}^{2+}$ with polarized nitrogen atoms in graphene nanosheet.

a

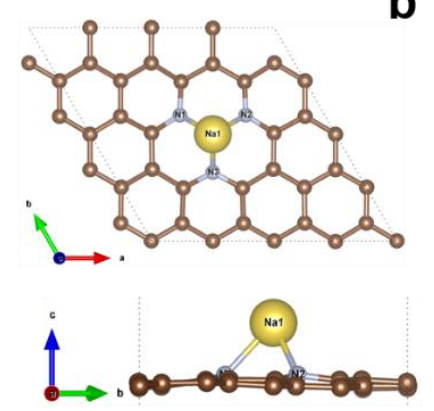

b

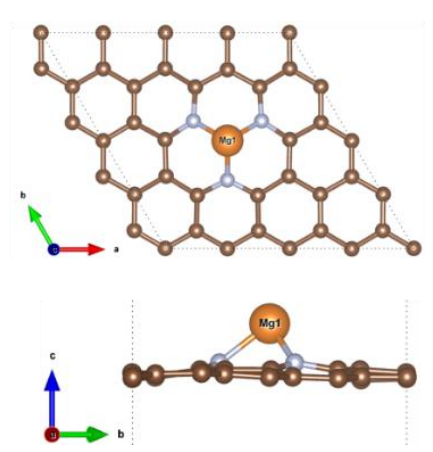

C

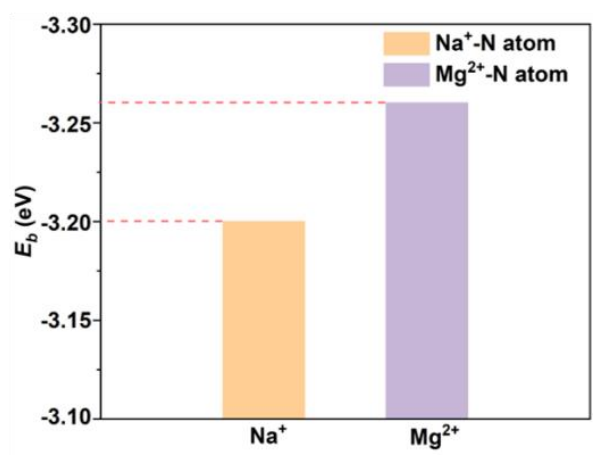

Figure S18. (a and b) Spheres in bronze and silver, represent carbon and nitrogen atoms in nitrogen-doped graphene (N@G). Spheres in yellow and orange, represent $\mathrm{Na}^{+}$and $\mathrm{Mg}^{2+}$ ions. Short line in bronze, silver, yellow and orange, represent the carbon-carbon bonds in aromatic structure, carbon-nitrogen bonds in $(\mathrm{N} @ \mathrm{G}), \mathrm{Na}^{+}$-nitrogen atom and $\mathrm{Mg}^{2+}$-nitrogen atom bonds. (c) The binding energies between metal ions and polarized nitrogen atom in $\mathrm{N} @ \mathrm{G}$ (labelled $\mathrm{Na}^{+}-\mathrm{N}^{2}$ atom and $\mathrm{Mg}^{2+}-\mathrm{N}^{2}$ atom). 


\section{Effect of $\mathrm{Na}^{+}$concentration on $\mathrm{Na}^{+}$permeation behavior through FGOM-30.}
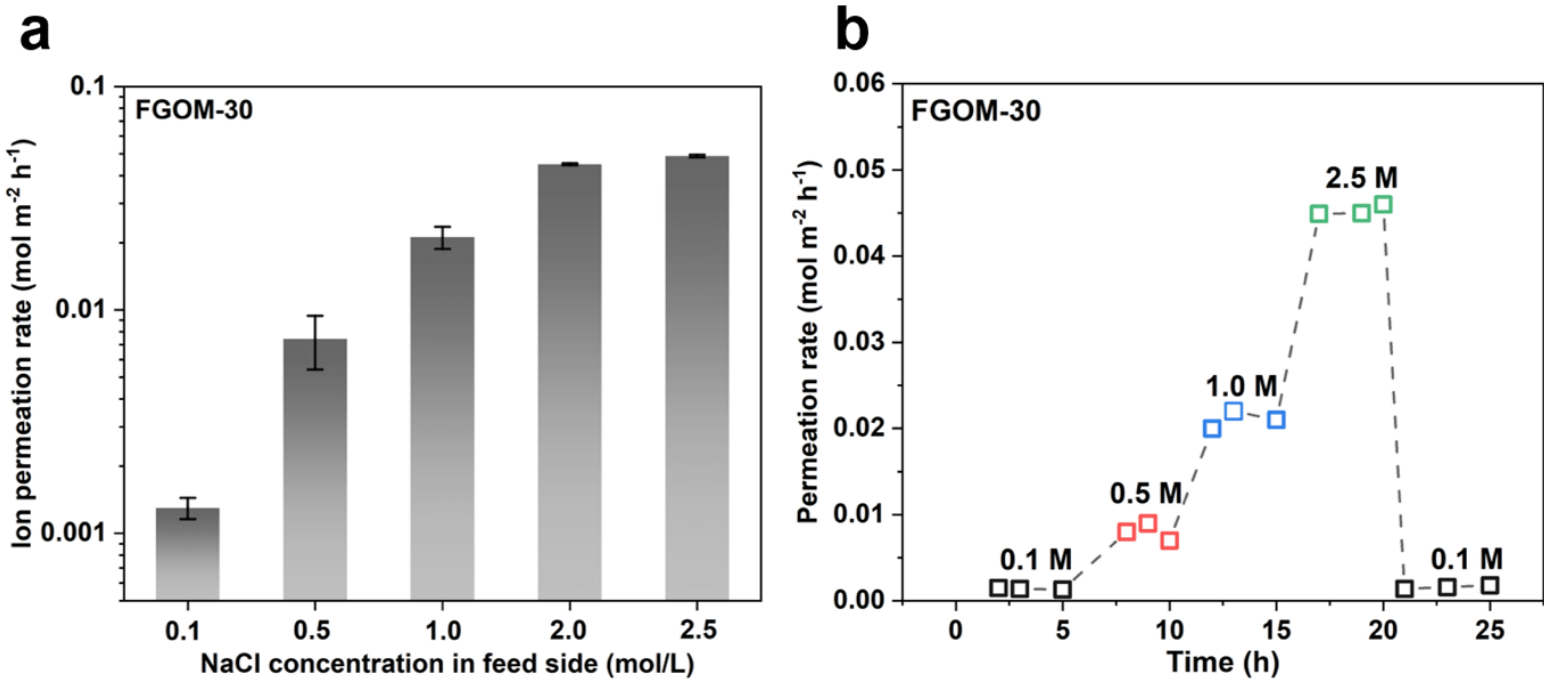

Figure S19. (a) Effect of $\mathrm{Na}^{+}$concentration on $\mathrm{Na}^{+}$permeation behavior through FGOM-30. We tested FGOM-30 with different concentrations of $\mathrm{NaCl}(20 \mathrm{~mL})$ as feed side and $20 \mathrm{~mL}$ DI water filled with permeated side. Error bars indicate the standard deviation from three different samples. With $\mathrm{NaCl}$ concentrations of 0.1 to $0.5 \mathrm{~mol} / \mathrm{L}$, the $\mathrm{Na}^{+}$permeation rates were below $0.01 \mathrm{~mol} \mathrm{~m}^{-2} \mathrm{~h}^{-1}$, demonstrating efficient ion rejection of plasma functionalisation. However, when the $\mathrm{NaCl}$ concentration exceeded $0.5 \mathrm{~mol} / \mathrm{L}$, the $\mathrm{Na}^{+}$permeation rates increased rapidly. This was because the significantly greater salt concentration increased the driving force behind $\mathrm{Na}^{+}$permeation, overcoming the electrostatic interaction, and facilitating fast transport of $\mathrm{Na}^{+}$. (b) Under a real-time changing of feed solution concentration. The concentration of $\mathrm{NaCl}$ in the feed side was increased from $0.1 \mathrm{M}$ to $2.5 \mathrm{M}$ with a certain interval of $5 \mathrm{~h}$, and then deceased to $0.1 \mathrm{M}$. Overall, the permeation rate of $\mathrm{Na}^{+}$was back to the initial state, indicating the long-term stability of FGOM-30. 


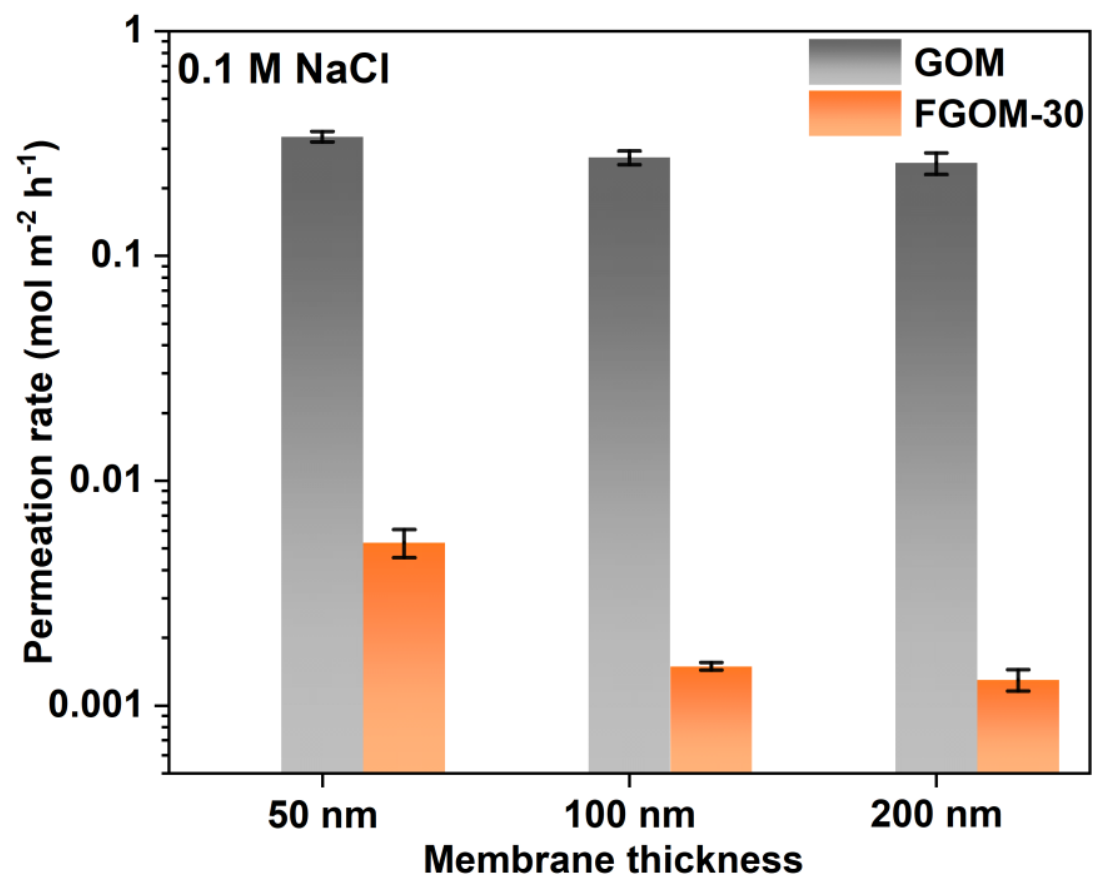

Figure S20. Effect of $\mathrm{Na}^{+}$permeation behaviour through FGOM-30 with different thickness. We tested the GOMs and FGOM-30 with the thickness of about $50 \mathrm{~nm}, 100 \mathrm{~nm}$ and $200 \mathrm{~nm}$, respectively. $20 \mathrm{~mL} 0.1 \mathrm{~mol} / \mathrm{L} \mathrm{NaCl}$ filled with feed side and $20 \mathrm{~mL}$ DI water filled with permeated side. Error bars indicate the standard deviation from three different samples. As shown in figure the permeation rate of $\mathrm{Na}^{+}$through all FGOMs was decreased by a factor at least of 60 when compared with that of GOMs. Even with a thickness of around $50 \mathrm{~nm}$, the FGOM-30 still remained a high $\mathrm{Na}^{+}$ion rejection and exhibited similar ion rejection performance to other FGOM-30, which is below $0.01 \mathrm{~mol} \mathrm{~m}^{-2} \mathrm{~h}^{-1}$. This result indicates that plasma functionalisation can efficiently endow ultrathin $\mathrm{GOM}$ with a high ion rejection of $\mathrm{NaCl}$. 
13. Water permeance and NaCl rejection of GOM and FGOMs by using osmosis-driven pressure.

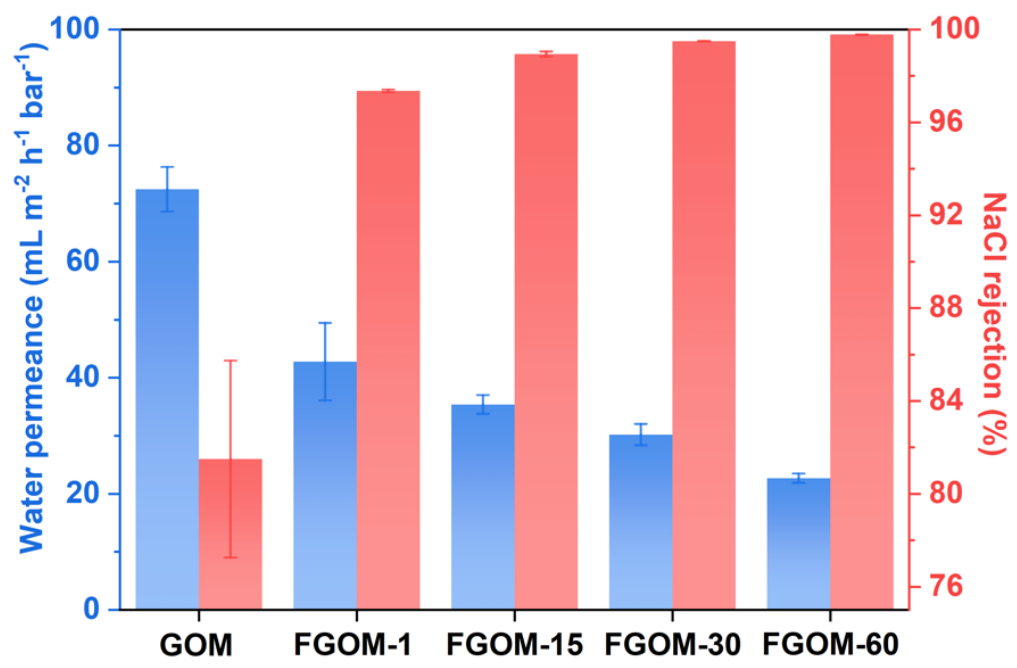

Figure S21. Water permeance and NaCl rejection of GOM and FGOMs by using osmosis-driven pressure. Obviously, the water permeance of FGOMs was decreased when compared with that of pristine GOM, which could be attributed to the strong hydrogen bonding formed between amine groups and water molecules, leading to a light loss of water permeance. The enhanced ion rejection shown in FGOMs reflected a synthetic influence of nitrogen functional groups and minimized $d$-spacing regulation, where the compressed $d$-spacing decrease the mass transport and $\mathrm{Na}^{+}$forms electrostatic interaction with polarized $\mathrm{N}$ atoms. Note: the thicknesses of GOM and FGOMs are $\sim 200 \mathrm{~nm}$. 
Table S1. Mono-/di-valent metal ion selectivity $\left(S_{\mathrm{K}^{+} / \mathrm{Ca}^{2+}}, S_{\mathrm{K}^{+} / \mathrm{Mg}^{2+}}\right.$ and $\left.S_{\mathrm{Na}^{+} / \mathrm{Mg}^{2+}}\right), \mathrm{K}^{+}$ permeance $\left(J_{K^{+}}\right)$achieved by various types of artificial channels and $2 \mathrm{D}$ nanomaterial membranes with different thickness measured under different feed electrolyte solution concentrations $\left(\mathbf{C}_{\text {feed }}\right)$.

\begin{tabular}{|c|c|c|c|c|c|c|c|c|}
\hline $\begin{array}{c}\text { Membrane } \\
\text { materials }\end{array}$ & Thickness & $\mathbf{C}_{\text {feed }}$ & $S_{K^{+} / C a^{2+}}$ & $S_{K^{+} / M g^{2+}}$ & $S_{\mathrm{Na}^{+} / \mathrm{Mg}^{2+}}$ & $J_{K^{+}}\left(\mathrm{mol} \mathrm{m} \mathbf{m}^{-2} \mathbf{h}^{-1}\right)$ & $\begin{array}{c}\text { Driving } \\
\text { force }\end{array}$ & Ref. \\
\hline FGOM-1 & \multirow{9}{*}{$200 \mathrm{~nm}$} & \multirow{4}{*}{$0.1 \mathrm{M}$} & 6.4 & 9.7 & 6.5 & $5.5 \times 10^{-2}$ & \multirow{9}{*}{$\Delta \mathrm{C}$} & \multirow{9}{*}{$\begin{array}{l}\text { This } \\
\text { work }\end{array}$} \\
\hline FGOM-15 & & & 3.2 & 11.0 & 10.3 & $3.6 \times 10^{-3}$ & & \\
\hline FGOM-30 & & & 25.4 & 50.0 & 31.1 & $1.9 \times 10^{-3}$ & & \\
\hline FGOM-60 & & & 56.0 & 90.3 & 40.3 & $8.9 \times 10^{-4}$ & & \\
\hline Pristine GOMs & & \multirow{5}{*}{$0.2 \mathrm{M}$} & $2.9 *$ & $3.2 *$ & $1.9^{*}$ & \multirow{5}{*}{$\mathrm{n} / \mathrm{a}$} & & \\
\hline FGOM-1 & & & $3.7 *$ & $4.7 *$ & $2.3 *$ & & & \\
\hline FGOM-15 & & & $7.8^{*}$ & $12.0 *$ & $5.0 *$ & & & \\
\hline FGOM-30 & & & $11.1 *$ & $17.0^{*}$ & $10.0^{*}$ & & & \\
\hline FGOM-60 & & & $18.2 *$ & $28.3^{*}$ & $14.4^{*}$ & & & \\
\hline \multirow{2}{*}{$\begin{array}{c}\text { Ion beam } \\
\text { engineered } \\
\text { GOM }\end{array}$} & $100 \mathrm{~nm}$ & \multirow{2}{*}{$\begin{array}{c}0.25 \\
\mathrm{M}\end{array}$} & 3.8 & 5.2 & $\mathrm{n} / \mathrm{a}$ & $1.9 \times 10^{-3}$ & \multirow[b]{2}{*}{$\Delta \mathrm{C}$} & \multirow{2}{*}[{}^{5}]{} \\
\hline & $200 \mathrm{~nm}$ & & 5.1 & 7.1 & $\mathrm{n} / \mathrm{a}$ & $4.5 \times 10^{-3}$ & & \\
\hline $\begin{array}{l}\text { Graphene } \\
\text { nanopore }\end{array}$ & $0.6 \mathrm{~nm}$ & 0.1 & $\mathrm{n} / \mathrm{a}$ & 4.0 & 3.4 & $\mathrm{n} / \mathrm{a}$ & $\mathrm{U}=1 \mathrm{~V}$ & {$\left[{ }^{6}\right]$} \\
\hline $\begin{array}{c}\text { Physically } \\
\text { confined GOM }\end{array}$ & $1000 \mu \mathrm{m}$ & $1 \mathrm{M}$ & $\mathrm{n} / \mathrm{a}$ & 650.0 & 420 & $\leq 7 \times 10^{-3}$ & $\Delta \mathrm{C}$ & {$\left[{ }^{7}\right]$} \\
\hline rGOMs & $2.16 \mu \mathrm{m}$ & $0.1 \mathrm{M}$ & $\mathrm{n} / \mathrm{a}$ & $169.0 *$ & $48 *$ & 0.19 & $\Delta \mathrm{C}$ & {$\left[{ }^{8}\right]$} \\
\hline GOM & $5 \mu \mathrm{m}$ & $1 \mathrm{M}$ & 1.1 & 1.1 & 1.0 & 3.0 & $\Delta \mathrm{C}$ & {$\left[{ }^{9}\right]$} \\
\hline $\begin{array}{c}\text { Nitrogen-dpoed } \\
\text { graphene } \\
\text { membrane }\end{array}$ & $\mathrm{n} / \mathrm{a}$ & $0.1 \mathrm{M}$ & $\mathrm{n} / \mathrm{a}$ & 390.0 & 80.0 & 0.1 & $\Delta \mathrm{C}$ & {$\left[{ }^{10}\right]$} \\
\hline $\begin{array}{c}\text { Diamines } \\
\text { crosslinked } \\
\text { GOM }\end{array}$ & $2 \mu \mathrm{m}$ & $0.1 \mathrm{M}$ & $\mathrm{n} / \mathrm{a}$ & $7.2 *$ & $4.8^{*}$ & 0.1 & $\Delta \mathrm{C}$ & {$\left[{ }^{11}\right]$} \\
\hline $\begin{array}{c}\text { Partially } \\
\text { rGO/chitosan } \\
\text { membrane } \\
\end{array}$ & $250 \mu \mathrm{m}$ & $5 \mathrm{mM}$ & $\mathrm{n} / \mathrm{a}$ & $\mathrm{n} / \mathrm{a}$ & 33.8 & $\mathrm{n} / \mathrm{a}$ & $\begin{array}{c}\Delta \mathrm{P}=5 \\
\text { bar }\end{array}$ & {$\left[{ }^{12}\right]$} \\
\hline $\begin{array}{c}\mathrm{H}_{2} \text { plasma- } \\
\text { treated } \\
\text { CVD graphene } \\
\text { polysulfone } \\
\text { membrane }\end{array}$ & $10 \mu \mathrm{m}$ & $0.5 \mathrm{M}$ & $\mathrm{n} / \mathrm{a}$ & 15.6 & 6.0 & 0.6 & $\Delta \mathrm{C}$ & {$\left[{ }^{13}\right]$} \\
\hline $\begin{array}{c}\mathrm{Ti}_{3} \mathrm{C}_{2} \mathrm{~T}_{\mathrm{x}} \text { MXene } \\
\text { membrane }\end{array}$ & $1.5 \mu \mathrm{m}$ & $0.2 \mathrm{M}$ & 4.1 & 5.9 & 9.6 & 0.9 & $\Delta \mathrm{C}$ & {$\left[{ }^{14}\right]$} \\
\hline $\begin{array}{l}\text { Zwitterion- } \\
\text { Carbon } \\
\text { nanotube } \\
\text { membrane }\end{array}$ & $0.2 \mu \mathrm{m}$ & $\mathrm{n} / \mathrm{a}$ & $\mathrm{n} / \mathrm{a}$ & 10.2 & 10.4 & $\mathrm{n} / \mathrm{a}$ & $\begin{array}{c}\Delta \mathrm{P}=1 \\
\text { bar }\end{array}$ & {$\left[{ }^{15}\right]$} \\
\hline $\begin{array}{c}\text { Graphite/MoS } \\
\text { 2D } \\
\text { channel }\end{array}$ & $7 \mu \mathrm{m}$ & $0.1 \mathrm{M}$ & $\mathrm{n} / \mathrm{a}$ & 2.3 & 2.0 & $\mathrm{n} / \mathrm{a}$ & $\mathrm{U}=0.2 \mathrm{~V}$ & {$\left[{ }^{16}\right]$} \\
\hline $\mathrm{MoS}_{2}$ nanopore & $0.65 \mathrm{~nm}$ & $1 \mathrm{M}$ & $\mathrm{n} / \mathrm{a}$ & 1.3 & 3.0 & $\mathrm{n} / \mathrm{a}$ & $\mathrm{U}=0.2 \mathrm{~V}$ & {$\left[{ }^{17}\right]$} \\
\hline
\end{tabular}


Table S2. Comparison of the 2D nanomaterial membranes for water/salt separation in a diffusion cell, where water/salt selectivity represents $\left(J_{\mathrm{w}} / J_{\mathrm{s}}\right)$ and osmotic pressure is calculated by van't Hoff equation $\left(* \Delta \pi_{\text {theo }}\right)$.

\begin{tabular}{|c|c|c|c|c|c|c|c|c|}
\hline $\begin{array}{l}\text { Membrane } \\
\text { materials }\end{array}$ & Thickness & $\begin{array}{l}{ }^{*} \Delta \pi_{t h e o} \\
\text { (bar) }\end{array}$ & $\begin{array}{c}J_{w} \\
\left(\mathrm{~mol} \mathrm{~m}^{-2} \mathbf{h}^{-1}\right)\end{array}$ & $\begin{array}{c}J_{\mathrm{w}} / \Delta \pi_{\text {theo }} \\
\left(\mathrm{mol} \mathrm{m}^{-2} \mathbf{h}^{-1} \text { bar }^{-1}\right)\end{array}$ & $\begin{array}{c}J_{s} \\
\text { (salts pieces) } \\
\left(\mathrm{mol} \mathrm{m}^{-2} \mathbf{h}^{-1}\right)\end{array}$ & $\begin{array}{l}\text { Selectivity } \\
\qquad\left(J_{w} / J_{s}\right)\end{array}$ & $\begin{array}{c}\text { Ion } \\
\text { rejection } \\
(\%)\end{array}$ & Ref. \\
\hline FGOM-1 & \multirow{3}{*}{$200 \mathrm{~nm}$} & \multirow{6}{*}{24.46} & 58.13 & 2.38 & $7.33 \times 10^{-2}(\mathrm{NaCl})$ & 792 & 97.4 & \multirow{6}{*}{$\begin{array}{l}\text { This } \\
\text { work }\end{array}$} \\
\hline FGOM-15 & & & 48.10 & 1.97 & $2.94 \times 10^{-2}(\mathrm{NaCl})$ & $1.63 \times 10^{3}$ & 98.9 & \\
\hline FGOM-30 & & & 41.07 & 1.68 & $1.38 \times 10^{-2}(\mathrm{NaCl})$ & $2.96 \times 10^{3}$ & 99.5 & \\
\hline FGOM-30 & $100 \mathrm{~nm}$ & & 61.13 & 2.50 & $2.22 \times 10^{-2}(\mathrm{NaCl})$ & $2.75 \times 10^{3}$ & 99.2 & \\
\hline FGOM-30 & $50 \mathrm{~nm}$ & & 119.70 & 4.89 & $2.77 \times 10^{-2}(\mathrm{NaCl})$ & $4.31 \times 10^{3}$ & 99.0 & \\
\hline FGOM-60 & $200 \mathrm{~nm}$ & & 30.83 & 1.26 & $6.11 \times 10^{-3}(\mathrm{NaCl})$ & $5.04 \times 10^{3}$ & 99.7 & \\
\hline$l \mathrm{GP}$ & \multirow{3}{*}{$3000 \mathrm{~nm}$} & \multirow{3}{*}{75} & 262.50 & 3.5 & \multirow{3}{*}{$\mathrm{n} / \mathrm{a}$} & \multirow{3}{*}{$\mathrm{n} / \mathrm{a}$} & 96.9 & \multirow{3}{*}[{}^{18}]{} \\
\hline$m \mathrm{GP}$ & & & 104.25 & 1.39 & & & 98.1 & \\
\hline$s \mathrm{GP}$ & & & 75 & 1.00 & & & 99.5 & \\
\hline rGO-GO & $5000 \mathrm{~nm}$ & \multirow{2}{*}{75} & 27.8 & 0.37 & \multirow{2}{*}{$\mathrm{n} / \mathrm{a}$} & \multirow{2}{*}{$\mathrm{n} / \mathrm{a}$} & 97 & \multirow{2}{*}[{}^{7}]{} \\
\hline rGO-GO & $1000 \mathrm{~nm}$ & & 139 & 1.85 & & & 94 & \\
\hline $\mathrm{KCl}-\mathrm{GO}$ & \multirow[t]{2}{*}{$280 \mathrm{~nm}$} & \multirow{6}{*}{12} & 20 & 1.67 & $4.8 \times 10^{-3}(\mathrm{NaCl})$ & $4.17 \times 10^{3}$ & \multirow{2}{*}{$\mathrm{n} / \mathrm{a}$} & \multirow{6}{*}[{}^{19}]{} \\
\hline GOM & & & 47.22 & 3.94 & 0.9 & 52.47 & & \\
\hline $\mathrm{KCl}-\mathrm{GO}$ & \multirow[t]{2}{*}{$550 \mathrm{~nm}$} & & 12.78 & 1.06 & $2.0 \times 10^{-3}(\mathrm{NaCl})$ & $6.39 \times 10^{3}$ & \multirow{2}{*}{$\mathrm{n} / \mathrm{a}$} & \\
\hline GOM & & & 27.22 & 2.27 & 0.32 & 85.06 & & \\
\hline $\mathrm{KCl}-\mathrm{GO}$ & $750 \mathrm{~nm}$ & & 5.56 & 0.46 & $2.7 \times 10^{-4}(\mathrm{NaCl})$ & $2.06 \times 10^{4}$ & 99 & \\
\hline GOM & $750 \mathrm{~nm}$ & & 9.44 & 0.79 & 0.19 & 49.68 & $\mathrm{n} / \mathrm{a}$ & \\
\hline $\begin{array}{c}\text { Non- } \\
\text { covalent } \\
\text { functionalis } \\
\text { ed GOM }\end{array}$ & $5300 \mathrm{~nm}$ & 75 & 138.3 & 1.84 & $\mathrm{n} / \mathrm{a}$ & $\mathrm{n} / \mathrm{a}$ & 95 & {$\left[{ }^{20}\right]$} \\
\hline $\begin{array}{l}\text { Pristine } \\
\mathrm{MoS}_{2}\end{array}$ & \multirow[b]{2}{*}{$5000 \mathrm{~nm}$} & 25 & 80.5 & 3.22 & $\mathrm{n} / \mathrm{a}$ & $\mathrm{n} / \mathrm{a}$ & $\mathrm{n} / \mathrm{a}$ & \multirow[b]{2}{*}[{}^{21}]{} \\
\hline $\begin{array}{c}\text { Dye } \\
\text { functionalis } \\
\text { ed } \mathrm{MoS}_{2}\end{array}$ & & 75 & 39 & 1.83 & $0.15(\mathrm{NaCl})$ & 260 & 99 & \\
\hline $\mathrm{MoS}_{2}$ & $\mathrm{n} / \mathrm{a}$ & 75 & 9 & 0.12 & $0.86(\mathrm{NaCl})$ & 6.80 & $\mathrm{n} / \mathrm{a}$ & {$[22]$} \\
\hline SCCM-120 & \multirow{2}{*}{$500 \mathrm{~nm}$} & \multirow{2}{*}{4.89} & \multirow{2}{*}{13.93} & 2.85 & $\sim 8.0 \times 10^{-3}(\mathrm{NaCl})$ & $3.60 \times 10^{3}$ & 98 & \multirow{2}{*}[{}^{23}]{} \\
\hline SCCM-180 & & & & 2.86 & $6.7 \times 10^{-3}(\mathrm{NaCl})$ & $2.70 \times 10^{3}$ & 98 & \\
\hline $\begin{array}{l}\text { 2D Al- } \\
\text { MOF }\end{array}$ & $100 \mathrm{~nm}$ & 24 & 2.44 & 0.10 & $1.5 \times 10^{-4}(\mathrm{NaCl})$ & $1.63 \times 10^{4}$ & 100 & {$\left[{ }^{24}\right]$} \\
\hline
\end{tabular}


Table S3. Comparison of the desalination performance of various lamellar membranes.

\begin{tabular}{|c|c|c|c|c|c|c|}
\hline $\begin{array}{c}\text { Membrane } \\
\text { materials }\end{array}$ & Thickness & $\begin{array}{l}\text { Operation } \\
\text { mode }\end{array}$ & $\begin{array}{c}\text { Feed salt } \\
\text { concentration } \\
(\mathrm{M})\end{array}$ & 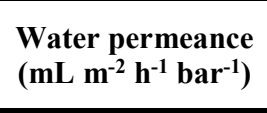 & $\begin{array}{c}\text { Ion rejection } \\
(\%)\end{array}$ & Ref. \\
\hline FGOM-1 & $200 \mathrm{~nm}$ & \multirow{6}{*}{$\begin{array}{l}\text { Forward } \\
\text { osmosis }\end{array}$} & \multirow{6}{*}{$0.1 \mathrm{M}$} & 42.78 & 97.4 & \multirow{6}{*}{ This work } \\
\hline FGOM-15 & $200 \mathrm{~nm}$ & & & 35.4 & 98.9 & \\
\hline \multirow{3}{*}{ FGOM-30 } & $200 \mathrm{~nm}$ & & & 30.22 & 99.5 & \\
\hline & $100 \mathrm{~nm}$ & & & 50.14 & 99.2 & \\
\hline & $50 \mathrm{~nm}$ & & & 88.08 & 99.0 & \\
\hline FGOM-60 & $200 \mathrm{~nm}$ & & & 22.62 & 99.7 & \\
\hline$l \mathrm{GP}$ & \multirow{3}{*}{$3000 \mathrm{~nm}$} & \multirow{3}{*}{$\begin{array}{l}\text { Forward } \\
\text { osmosis }\end{array}$} & \multirow{3}{*}{$0.1 \mathrm{M}$} & 63 & 96.9 & \multirow{3}{*}[{}^{14}]{} \\
\hline$m \mathrm{GP}$ & & & & 25 & 98.1 & \\
\hline$s \mathrm{GP}$ & & & & 18 & 99.5 & \\
\hline \multirow{2}{*}{ PCGO } & $5000 \mathrm{~nm}$ & Forward & \multirow{2}{*}{$0.1 \mathrm{M}$} & 7 & 97 & \multirow{2}{*}[{}^{7}]{} \\
\hline & $1000 \mathrm{~nm}$ & osmosis & & 33 & 94 & \\
\hline \multirow{3}{*}{$\mathrm{KCl}-\mathrm{GO}$} & $280 \mathrm{~nm}$ & \multirow{3}{*}{$\begin{array}{l}\text { Forward } \\
\text { osmosis }\end{array}$} & \multirow{3}{*}{$0.25 \mathrm{M}$} & 28.8 & $\mathrm{n} / \mathrm{a}$ & \multirow{3}{*}[{}^{19}]{} \\
\hline & $550 \mathrm{~nm}$ & & & 18.4 & $\mathrm{n} / \mathrm{a}$ & \\
\hline & $750 \mathrm{~nm}$ & & & 8.0 & 99 & \\
\hline $\begin{array}{l}\text { Non-covalent } \\
\text { functionalised } \\
\text { GOM }\end{array}$ & $5300 \mathrm{~nm}$ & $\begin{array}{l}\text { Forward } \\
\text { osmosis }\end{array}$ & $0.2 \mathrm{M}$ & 34.6 & 95 & {$\left[{ }^{20}\right]$} \\
\hline $\begin{array}{l}\text { Dye-functionalised } \\
\qquad \mathrm{MoS}_{2}\end{array}$ & $5 \mathrm{~mm}$ & $\begin{array}{l}\text { Forward } \\
\text { osmosis }\end{array}$ & $0.1 \mathrm{M}$ & 33.0 & 99 & {$\left[{ }^{21}\right]$} \\
\hline \multicolumn{7}{|l|}{ (Self-crosslinking } \\
\hline MXene) & \multirow{4}{*}{$500 \mathrm{~nm}$} & \multirow{4}{*}{$\begin{array}{l}\text { Forward } \\
\text { osmosis }\end{array}$} & \multirow{4}{*}{$0.1 \mathrm{M}$} & 59.5 & 97 & \multirow{4}{*}[{}^{23}]{} \\
\hline SCCM-80 & & & & 51.3 & 98 & \\
\hline SCCM-120 & & & & 51.5 & 98 & \\
\hline SCCM-180 & & & & & & \\
\hline
\end{tabular}




\section{Reference}

1. $\quad$ Chen, Z.; Dai, X. J.; Magniez, K.; Lamb, P. R.; de Celis Leal, D. R.; Fox, B. L.; Wang, X., Improving the mechanical properties of epoxy using multiwalled carbon nanotubes functionalized by a novel plasma treatment. Composites Part A: Applied Science and Manufacturing 2013, 45, 145-152.

2. Reynosa-Martínez, A.; Tovar, G. N.; Gallegos, W.; Rodríguez-Meléndez, H.; Torres-Cadena, R.; Mondragón-Solórzano, G.; Barroso-Flores, J.; Alvarez-Lemus, M.; Montalvo, V. G.; LópezHonorato, E., Effect of the degree of oxidation of graphene oxide on As (III) adsorption. Journal of hazardous materials 2020, 384, 121440.

3. Lei, W.; Mochalin, V. N.; Liu, D.; Qin, S.; Gogotsi, Y.; Chen, Y., Boron nitride colloidal solutions, ultralight aerogels and freestanding membranes through one-step exfoliation and functionalization. Nature communications 2015, 6 (1), 1-8.

4. Cançado, L. G.; Jorio, A.; Ferreira, E. M.; Stavale, F.; Achete, C. A.; Capaz, R. B.; Moutinho, M. V. d. O.; Lombardo, A.; Kulmala, T.; Ferrari, A. C., Quantifying defects in graphene via Raman spectroscopy at different excitation energies. Nano letters 2011, 11 (8), 3190-3196.

5. Wei, Y.; Pastuovic, Z.; Shen, C.; Murphy, T.; Gore, D. B., Ion beam engineered graphene oxide membranes for mono-/di-valent metal ions separation. Carbon 2020, 158, 598-606.

6. Rollings, R. C.; Kuan, A. T.; Golovchenko, J. A., Ion selectivity of graphene nanopores. Nature communications 2016, 7 (1), 1-7.

7. Abraham, J.; Vasu, K. S.; Williams, C. D.; Gopinadhan, K.; Su, Y.; Cherian, C. T.; Dix, J.; Prestat, E.; Haigh, S. J.; Grigorieva, I. V., Tunable sieving of ions using graphene oxide membranes. Nature nanotechnology 2017, 12 (6), 546.

8. $\quad$ Xi, Y.-H.; Liu, Z.; Ji, J.; Wang, Y.; Faraj, Y.; Zhu, Y.; Xie, R.; Ju, X.-J.; Wang, W.; Lu, X., Graphene-based membranes with uniform 2D nanochannels for precise sieving of mono-/multivalent metal ions. Journal of Membrane Science 2018, 550, 208-218.

9. Joshi, R.; Carbone, P.; Wang, F.-C.; Kravets, V. G.; Su, Y.; Grigorieva, I. V.; Wu, H.; Geim, A. K.; Nair, R. R., Precise and ultrafast molecular sieving through graphene oxide membranes. science 2014, 343 (6172), 752-754.

10. Song, J. H.; Yu, H. W.; Ham, M. H.; Kim, I. S., Tunable Ion Sieving of Graphene Membranes through the Control of Nitrogen-Bonding Configuration. Nano Lett 2018, 18 (9), 5506-5513.

11. Jia, Z.; Wang, Y.; Shi, W.; Wang, J., Diamines cross-linked graphene oxide free-standing membranes for ion dialysis separation. Journal of Membrane Science 2016, 520, 139-144.

12. Wei, Y.; Wang, J.; Li, H.; Zhao, M.; Zhang, H.; Guan, Y.; Huang, H.; Mi, B.; Zhang, Y., Partially reduced graphene oxide and chitosan nanohybrid membranes for selective retention of divalent cations. RSC advances 2018, 8 (25), 13656-13663.

13. Li, S.; Lee, J.-H.; Hu, Q.; Oh, T.-S.; Yoo, J.-B., Scalable graphene composite membranes for enhanced ion selectivity. Journal of Membrane Science 2018, 564, 159-165.

14. Ren, C. E.; Hatzell, K. B.; Alhabeb, M.; Ling, Z.; Mahmoud, K. A.; Gogotsi, Y., Charge-and size-selective ion sieving through Ti3C2T x MXene membranes. The journal of physical chemistry letters 2015, 6 (20), 4026-4031.

15. Liu, T.-Y.; Yuan, H.-G.; Li, Q.; Tang, Y.-H.; Zhang, Q.; Qian, W.; Van der Bruggen, B.; Wang, X., Ion-responsive channels of zwitterion-carbon nanotube membrane for rapid water permeation and ultrahigh mono-/multivalent ion selectivity. ACS nano 2015, 9 (7), 7488-7496.

16. Esfandiar, A.; Radha, B.; Wang, F.; Yang, Q.; Hu, S.; Garaj, S.; Nair, R.; Geim, A.; Gopinadhan, K., Size effect in ion transport through angstrom-scale slits. Science 2017, 358 (6362), 511-513.

17. Feng, J.; Liu, K.; Graf, M.; Dumcenco, D.; Kis, A.; Di Ventra, M.; Radenovic, A., Observation of ionic Coulomb blockade in nanopores. Nature materials 2016, 15 (8), 850-855.

18. Hirunpinyopas, W.; Iamprasertkun, P.; Bissett, M. A.; Dryfe, R. A., Tunable charge/size selective ion sieving with ultrahigh water permeance through laminar graphene membranes. Carbon 2020, 156, 119-129.

19. Chen, L.; Shi, G.; Shen, J.; Peng, B.; Zhang, B.; Wang, Y.; Bian, F.; Wang, J.; Li, D.; Qian, Z., Ion sieving in graphene oxide membranes via cationic control of interlayer spacing. Nature 2017, 550 (7676), 380-383. 
20. Ran, J.; Chu, C.; Pan, T.; Ding, L.; Cui, P.; Fu, C.-F.; Zhang, C.-L.; Xu, T., Non-covalent cross-linking to boost the stability and permeability of graphene-oxide-based membranes. Journal of materials chemistry A 2019, 7 (14), 8085-8091.

21. Hirunpinyopas, W.; Prestat, E.; Worrall, S. D.; Haigh, S. J.; Dryfe, R. A.; Bissett, M. A., Desalination and nanofiltration through functionalized laminar MoS2 membranes. ACS nano 2017, 11 (11), 11082-11090.

22. Deng, M.; Kwac, K.; Li, M.; Jung, Y.; Park, H. G., Stability, molecular sieving, and ion diffusion selectivity of a lamellar membrane from two-dimensional molybdenum disulfide. Nano letters 2017, 17 (4), 2342-2348.

23. Lu, Z.; Wei, Y.; Deng, J.; Ding, L.; Li, Z. K.; Wang, H., Self-Crosslinked MXene (Ti3C2Tx) Membranes with Good Antiswelling Property for Monovalent Metal Ion Exclusion. ACS Nano 2019, 13 (9), 10535-10544.

24. Jian, M.; Qiu, R.; Xia, Y.; Lu, J.; Chen, Y.; Gu, Q.; Liu, R.; Hu, C.; Qu, J.; Wang, H., Ultrathin water-stable metal-organic framework membranes for ion separation. Science Advances 2020, 6 (23), eaay3998. 